\title{
Geology and Hydrology of the Piqua Area, Ohio
}

GEOLOGICAL SURVEY BULLETIN 1133 - A

Prepared on behalf of the

U.S. Atomic Energy Commission 


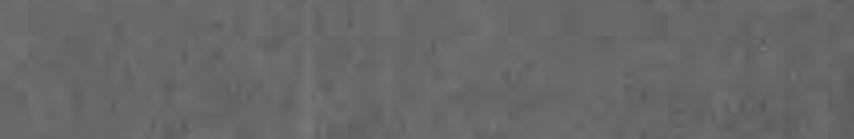

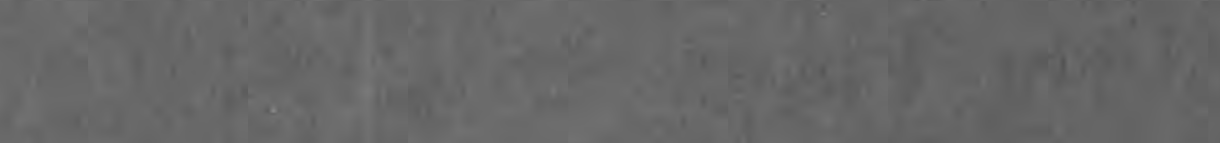

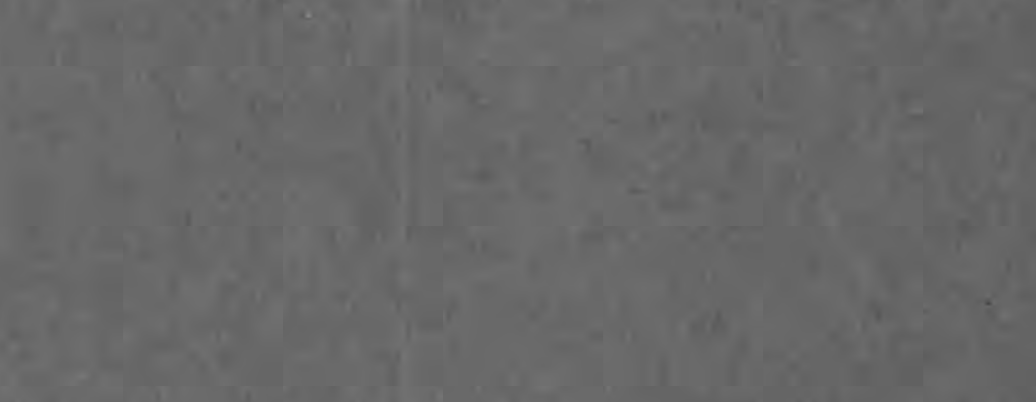

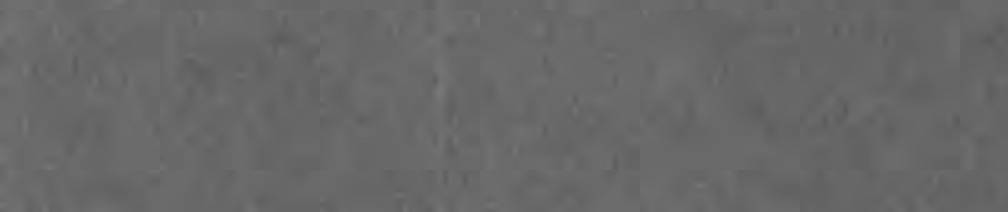

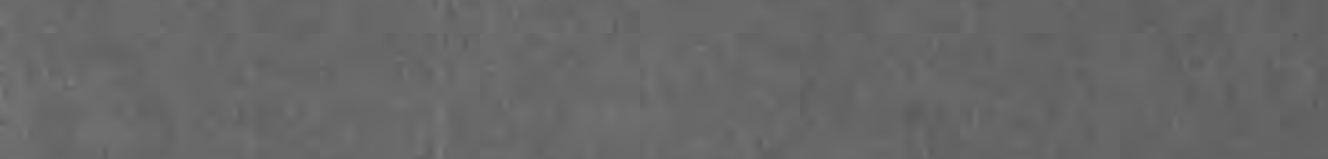
6

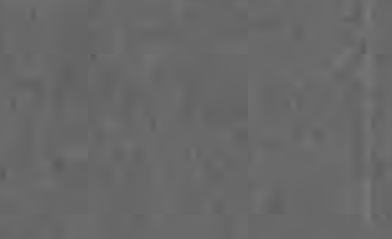

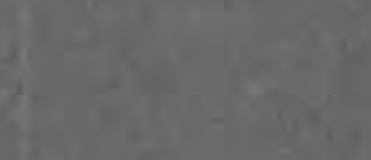

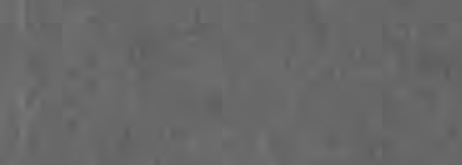

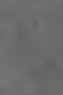

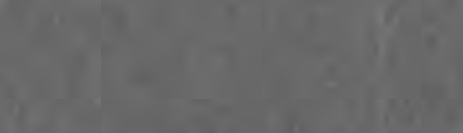

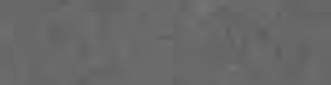

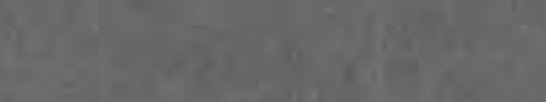

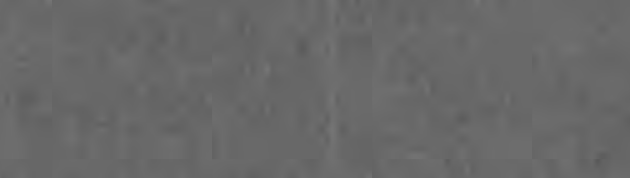

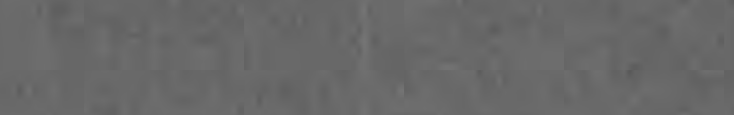

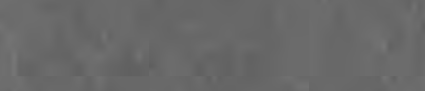

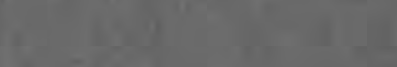

(9)

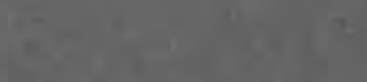

2. 9

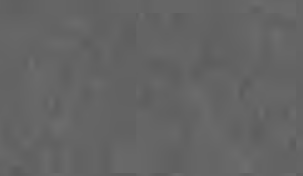

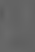

$=\frac{1}{2} \sin ^{\prime}$

it

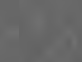

$6 y^{2}+y^{2}+1$

$v=-1,9$

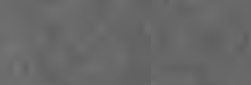

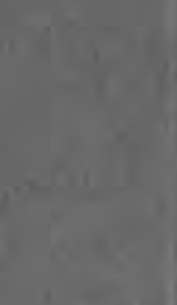

$1 \operatorname{lin}^{1}$

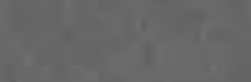

is

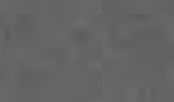

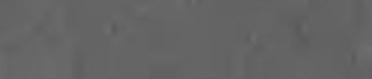

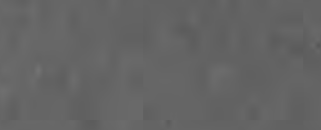




\section{Geology and Hydrology of the Piqua Area, Ohio}

By STANLEY E. NORRIS and ANDREW M. SPIEKER

STUDIES OF SITES FOR NUCLEAR ENERGY FACILITIES

GEOLOGICAL S URVEY B ULLE T IN 1133-A

Prepared on behalf of the

U.S. Atomic Energy Commission

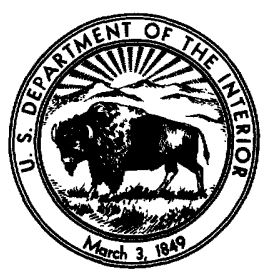




\title{
UNITED STATES DEPARTMENT OF THE INTERIOR
}

STEWART L. UDALL, Secretary

\author{
GEOLOGIGAL SURVEY \\ Thomas B. Nolan, Director
}

For sale by the Superintendent of Documents, U.S. Government Printing Office Washington 25, D.C. 


\section{CONTENTS}

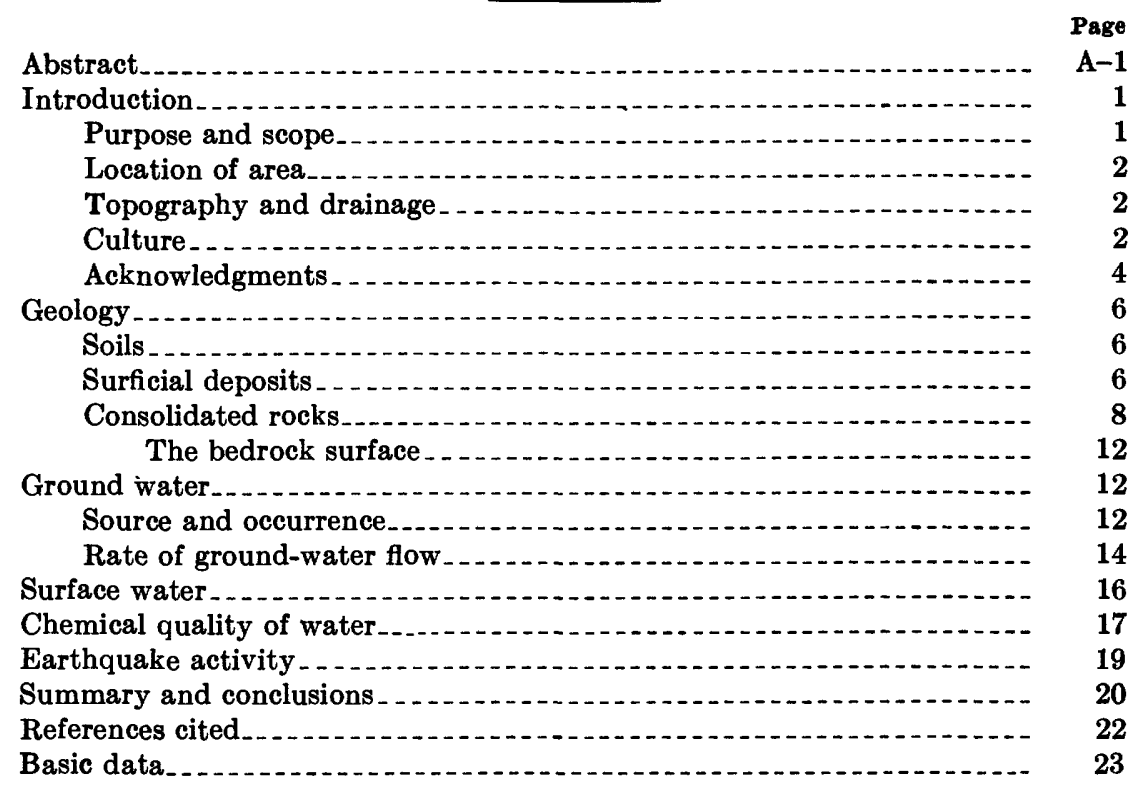

\section{ILLUSTRATIONS}

Figure 1. Aerial photograph of Piqua, Ohio

2. Map of Ohio showing location of the Piqua area...... 4

3. Topographic map of the Piqua area..... 5

4. Map showing glacial deposits _. 7

5. Map showing consolidated rocks and bedrock contours._._. 9

6. Exposure of Brassfield and Dayton limestones._. 10

7. Exposure of Brassfield limestone....... 11

8. Map showing location of wells

9. Flood-frequency diagram. 18

\section{TABLES}

TABle 1. Records of wells in the Piqua area, Ohio

A-24

2. Flow-duration data at two gaging stations near Piqua......

3. Monthly and annual discharge-at three gaging stations........

4. Momentary maximum, minimum daily, and annual mean discharge at two gaging stations near Piqua.......

5. Chemical analyses of water near Piqua... 



\title{
STUDIES OF SITES FOR NUCLEAR ENERGY FACILITIES
}

\section{GEOLOGY AND HYDROLOGY OF THE PIQUA AREA, OHIO}

\author{
By Stanley E. Norris and Andrew M. Spieker
}

\begin{abstract}
This report on the geology and hydrology of the Piqua area, Ohio, was prepared as an aid in determining the feasibility of operating a nuclear-power reactor at a site on the west bank of the Miami River in the southern part of Piqua.

Piqua is in Miami County in west-central Ohio, which is in the Till Plains section of the Central Lowlands physiographic province. The city is in the valley of the Miami River at an altitude of about 870 feet, about 100 feet below the surrounding till plain. The Dayton and Brassfield limestones of Silurian age and the Richmond group of Ordovician age, which compose the bedrock, are overlain by 20 to 40 feet of glacial till west of the Miami River and by a thick section, as much as 200 feet of till, east of the river. The Silurian limestones and the Pleistocene till and outwash deposits yield supplies adequate for domestic, rural, or limited industrial use. Several buried lenses of sand and gravel in the thick till east of Piqua are especially productive aquifers. The ground water is characteristically hard and has a high iron content.

The rate of movement of ground water in the Piqua area is probably on the order of $\mathbf{1 0}$ feet per day in the sand and gravel and a few inches per day in the till. Owing to the highly variable permeability of the limestones, the rate of ground-water movement in them has not been estimated.

The only significant use of surface water at Piqua is at locations upstream from the proposed reactor site. Downstream from Piqua, however, the Miami River is important as a source of municipal and industrial water supply, either directly or by induced infiltration to wells. About $200 \mathrm{mgd}$ (million gallons per day) of ground water is pumped from wells in the outwash sand and gravel deposits in the Miami River valley downstream from Piqua, most of it at Dayton, Middletown, and Hamilton. Probably 75 to 90 percent of the ground water has the Miami River as its source.

The site for the nuclear-power reactor is on the flood plain of the Miami River, and it requires protection against occasional floods.

Owing to the proximity of the site of the proposed nuclear reactor to the Miami River and to the hydraulic gradient of the aquifer, which slopes from the site toward the river, the greatest danger in the event of a leak in the reactor cell would be that the effluent could enter the river, either overland or through the ground water. Dilution and time of travel of a contaminant, once it entered the river, would depend on river conditions at the time. Detailed time-of-travel and dilution computations to individual water supplies located downstream cannot be made on the basis of presently available information.
\end{abstract}

\section{INTRODUCTION}

\section{PURPOSE AND SCOPE}

The purpose of this report is to present the geology and hydrology of the Piqua area, Ohio, with special reference to the effects of acci- 
dental loss of radioactive fluid to the ground. The report was prepared on behalf of the U.S. Atomic Energy Commission as an aid in determining the feasibility of operating a nuclear-power reactor at a site on the west bank of the Miami River in the southern part of Piqua (fig. 1).

Well data on which this report is based were obtained from the files of the Ohio Division of Water, and were supplemented by a field investigation made by the authors on July 15-17, 1958.

\section{LOCATION OF AREA}

Piqua is in west-central Ohio, about 80 miles west of Columbus and 30 miles north of Dayton, in the valley of the Miami River at an altitude of about 870 feet. (See fig. 2.)

\section{TOPOGRAPHY AND DRAINAGE}

Piqua is the Till Plains section of the Central Lowland physiographic province, a region characterized by generally flat topography except for minor relief along the streams and in areas of glacial moraines. The terrain west of Piqua, underlain by only a thin mantle of till over limestone, is nearly flat, whereas the terrain east of town, underlain by. as much as 200 feet of glacial drift over shale, has a much more pronounced relief. The town of Piqua is in the valley of the Miami River, about 100 feet lower than the adjacent till plain. North and east of Piqua is a belt of higher, hummocky land, a few miles wide, whose southern boundary forms a broad arc that extends through Lockington and Kirkwood (fig. 3). This belt of higher land is a recessional moraine formed during a temporary halt in the retreat of the final stage of the Wisconsin glacier.

The Miami River, the principal stream in western Ohio, has a drainage area above Piqua of 842 square miles. South of Piqua it flows through Troy, Dayton, Middletown, Hamilton, and several other cities, to a junction with the Ohio River near Cincinnati. Downstream from Piqua the Miami River is an important source of municipal and industrial water supply, either directly or by induced infiltration to wells.

An important tributary of the Miami River is Loramie Creek, which joins the Miami about 3 miles north of Piqua. Loramie Creek is regulated by a dam at Lockington, which is one of five detention dams built by the Miami Conservancy District to protect Dayton and other downstream cities from floods. The dams have automatic outlets and the reservoirs are kept empty except during flood periods.

\section{CULTURE}

Piqua, which has a population of about 20,000 (1957 estimate), is primarily an industrial community; 50 manufacturing establishments 


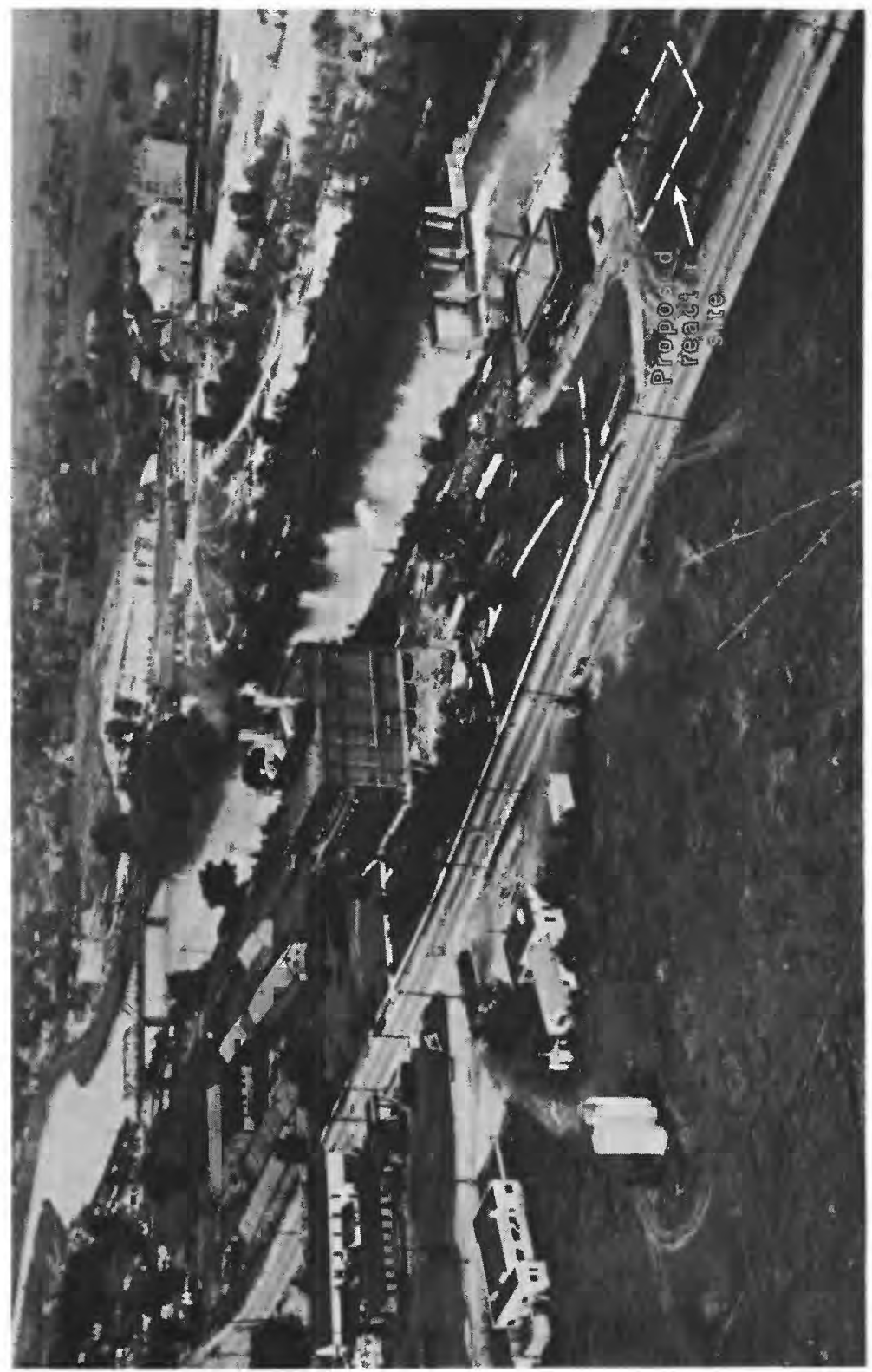

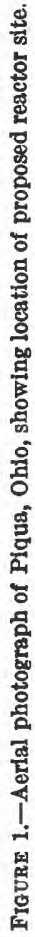




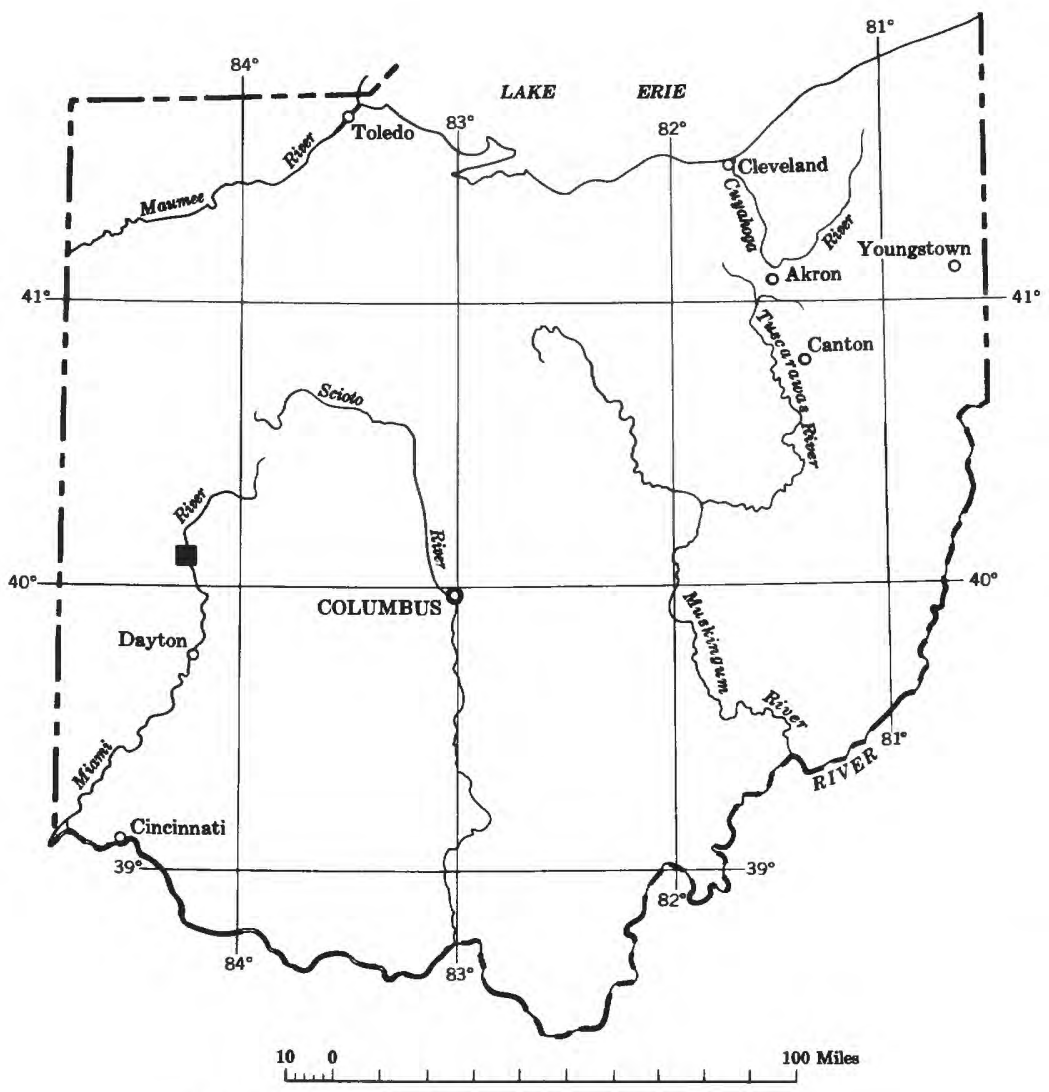

Figure 2.-Map of Ohio showing location of the Piqua area.

and 11 utility companies are located there. Most of the surrounding rural area consists of productive farmland. Piqua is served by the Baltimore and Ohio and Pennsylvania Railroads and by U.S. Highways 25 and 36 .

\section{ACKNOWLEDGMENTS}

General information on the Piqua area and aerial photographs of the proposed reactor site were supplied by Mr. John P. Gallagher, Director of Municipal Utilities, Piqua, Ohio. Most of the well records used in this report were supplied by the drilling firm of Hole and Middlebrook, Piqua, Ohio. Mr. Herbert Hole was very helpful to the authors in discussing with them general ground-water conditions in the Piqua area.

E. S. Simpson, U.S. Geological Survey, made a brief reconnaissance of the site and vicinity in company with the authors and made helpful suggestions with respect to the preparation of the report. 


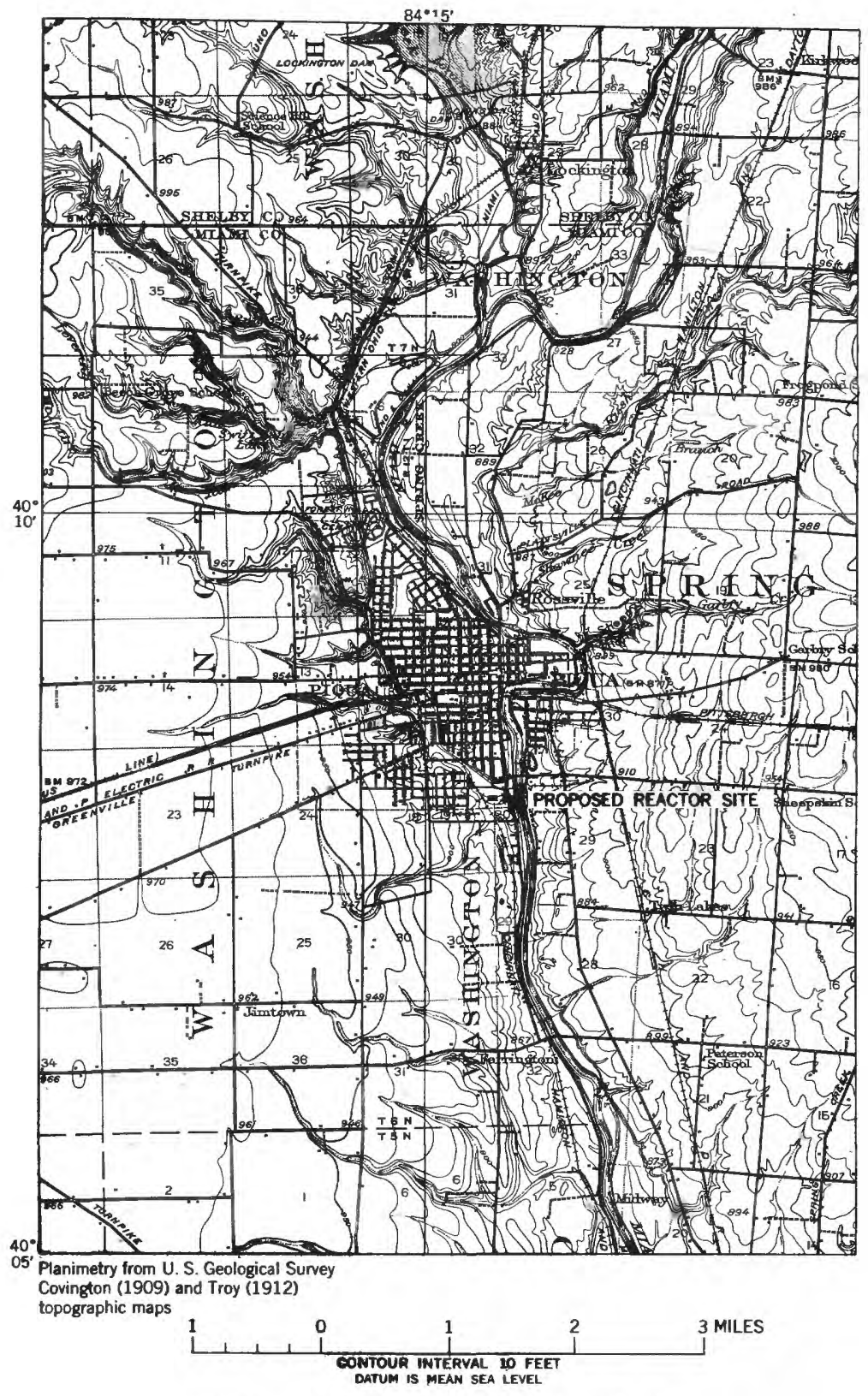

Figure 3.-Topographic map of the Piqua area, Ohio. 


\section{GEOLOGY \\ sorrs}

The soils in the Piqua area are derived from glacial deposits in which fragments of limestone are an important constituent. Richard B. Jones, Ohio Division of Lands and Soils (in Cross and Hedges, 1959, p. 51) stated:

The soils are derived from glacial deposits of both early and late Wisconsin Age. Miami, Celina, Crosby, and Brookston are the dominant soils of the late Wisconsin till area, and Russell, Xenia, and Fincastle are the principal soils of the early Wisconsin area. Classification of these soils depends on the drainage condition under which they developed. The less well-drained soils are relatively impermeable. Rather extensive terrace and alluvial soils occur, generally with good drainage and high permeability. Fox and associated soils are prevalent on the terraces. Genesee soils are the dominant alluvial soils.

The soil and underlying alluvium in the vicinity of the proposed reactor site are about 5 feet thick and directly overlie limestone. The soil is probably correlative with the Genesee series. The Genesee series (Conrey and others, 1934, p. 15) consists of nonacid silt loam that has fair to good natural drainage properties.

\section{SURFICIAL DEPOSITS}

The surficial deposits (fig. 4) in the Piqua area are of glacial and alluvial origin and consist of till on the uplands and generally of sand and gravel outwash in the Miami River valley. The flood plain of the Miami River is underlain by alluvial deposits of silt and clay, deposited by the stream during times it has overflowed its banks. At the proposed reactor site the alluvium is less than 5 feet thick and rests directly on the limestone bedrock.

The outwash sand and gravel deposits in the area are thickest and most extensive immediately north of Piqua at the site of a large commercial sand and gravel pit; they are thinner and of smaller areal extent both north and south of this pit. The deposits are less than 10 feet thick near the center of Piqua and pinch out entirely a few blocks north of the proposed reactor site. The sand and gravel deposits are absent in the narrow part of the valley between the reactor site and a point near Farrington, about 2 miles downstream. Below Farrington, along the rest of its course, the Miami valley contains extensive deposits of sand and gravel. For example, at well 54 , about 3 miles south of the reactor site (fig. 8), the sand and gravel is 68 feet thick.

On the upland west of Piqua the till is thin, 20 to 40 feet thick, and lies directly on the limestone bedrock. East of the town the till is comparatively thick, as much as 200 feet or more thick, and is interbedded with three or more fairly extensive sand and gravel layers which are sources of water to farm and domestic wells. These 


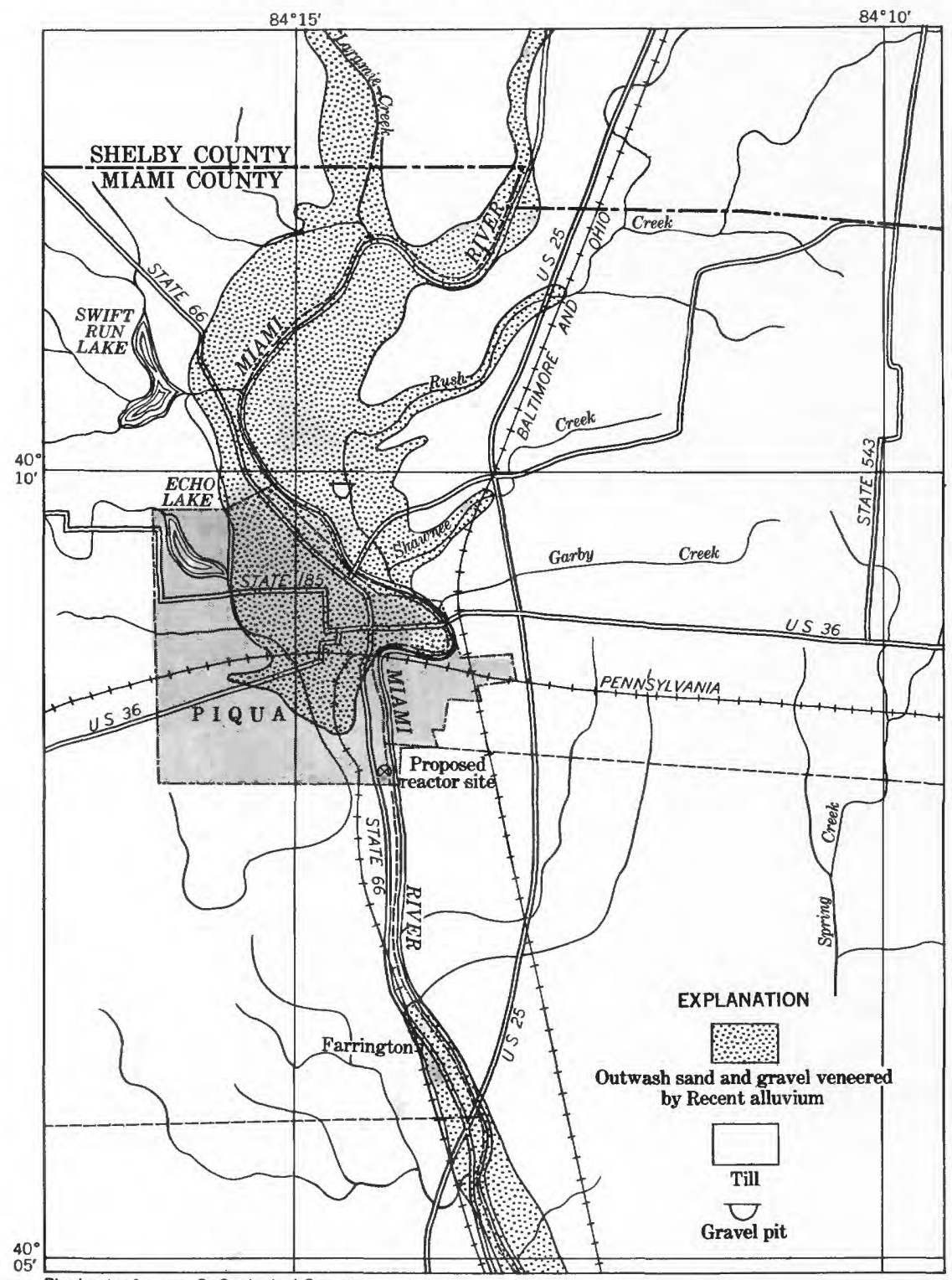

Planimetry from U. S. Geological Survey Covington (1909) and Troy (1912)

topographic maps

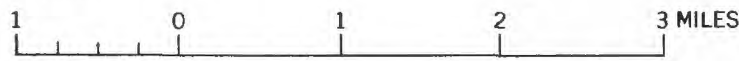

Figure 4. - Map of the Piqua area, Ohio, showing the distribution of the glacial deposits. 
buried sand and gravel lenses represent outwash fans or valley trains deposited by melt water as glacial fronts advanced or retreated over a lowland eroded by preglacial streams. These streams had cut through massive limestone into the underlying, less resistant shale. Some or all of the buried sand and gravel deposits may be absent from the stratigraphic sequence at specific sites east of Piqua, for they are not reported consistently by drillers. Detailed logs, however, usually show these layers, and the authors believe that some of these layers are generally extensive. The following logs are typical of the well records (table 1) that show these deposits.

\begin{tabular}{|c|c|c|c|c|c|}
\hline & $\begin{array}{l}\text { Thickness } \\
\text { (feet) }\end{array}$ & $\begin{array}{c}\text { Depth } \\
\text { (feet) }\end{array}$ & & $\underset{\text { (feet) }}{\text { Thickness }}$ & $\begin{array}{l}\text { Depth } \\
\text { (feet) }\end{array}$ \\
\hline \multicolumn{6}{|c|}{ Well 10} \\
\hline $\begin{array}{l}\text { Soil and till } \\
\text { Sand and gravel. } \\
\text { Till } \\
\text { Sand and gravel }\end{array}$ & $\begin{array}{r}25 \\
3 \\
32 \\
10\end{array}$ & $\begin{array}{l}25 \\
28 \\
60 \\
70\end{array}$ & $\begin{array}{l}\text { Till } \\
\text { Sand and gravel. } \\
\text { Till } \\
\text { Sand and gravel }\end{array}$ & $\begin{array}{l}50 \\
10 \\
10 \\
20\end{array}$ & $\begin{array}{l}120 \\
130 \\
140 \\
160\end{array}$ \\
\hline \multicolumn{6}{|c|}{ Well 18} \\
\hline $\begin{array}{l}\text { Soil and till } \\
\text { Sand and gravel. } \\
\text { Till } \\
\text { Sand and gravel. } \\
\text { Till }\end{array}$ & $\begin{array}{r}23 \\
11 \\
19 \\
8 \\
45\end{array}$ & $\begin{array}{r}23 \\
34 \\
53 \\
61 \\
106\end{array}$ & $\begin{array}{l}\text { Sand and gravel. } \\
\text { Till } \\
\text { Sand and gravel.- } \\
\text { Till or clay } \\
\text { Sand and gravel... }\end{array}$ & $\begin{array}{r}16 \\
27 \\
10 \\
4 \\
3\end{array}$ & $\begin{array}{l}122 \\
149 \\
159 \\
163 \\
166\end{array}$ \\
\hline \multicolumn{6}{|c|}{ Well 56} \\
\hline $\begin{array}{l}\text { Soil and till } \\
\text { Sand and gravel. } \\
\text { Till } \\
\text { Sand and gravel } \\
\text { Till } \\
\text { Sand and gravel }\end{array}$ & $\begin{array}{r}15 \\
17 \\
85 \\
13 \\
57 \\
9\end{array}$ & $\begin{array}{r}15 \\
32 \\
117 \\
130 \\
187 \\
196\end{array}$ & $\begin{array}{l}\text { Till } \\
\text { Sand } \ldots \\
\text { Clay } \\
\text { Sand } \\
\text { Till } \\
\text { Shale }\end{array}$ & $\begin{array}{r}8 \\
5 \\
1 \\
2 \\
4 \\
19\end{array}$ & $\begin{array}{l}204 \\
209 \\
210 \\
212 \\
216 \\
235\end{array}$ \\
\hline
\end{tabular}

Well 56 was logged by a gamma-ray logging device, owned by the driller, D. J. Roe, Vandalia, Ohio, and this log probably is the most accurate of the three. The well was screened between depths of 120 and 130 feet and 190 and 196 feet. A pumping test of well 56, at a rate of $400 \mathrm{gpm}$ (gallons per minute), produced a sizable drawdown in well 21 , nearly 3,000 feet distant (fig. 8 ); this drawdown indicates continuity of the princiapl aquifer between these points.

\section{CONSOLIDATED ROCKS}

The distribution of consolidated sedimentary rocks of Ordovician and Silurian age that underlie the Piqua area is shown in figure 5. 


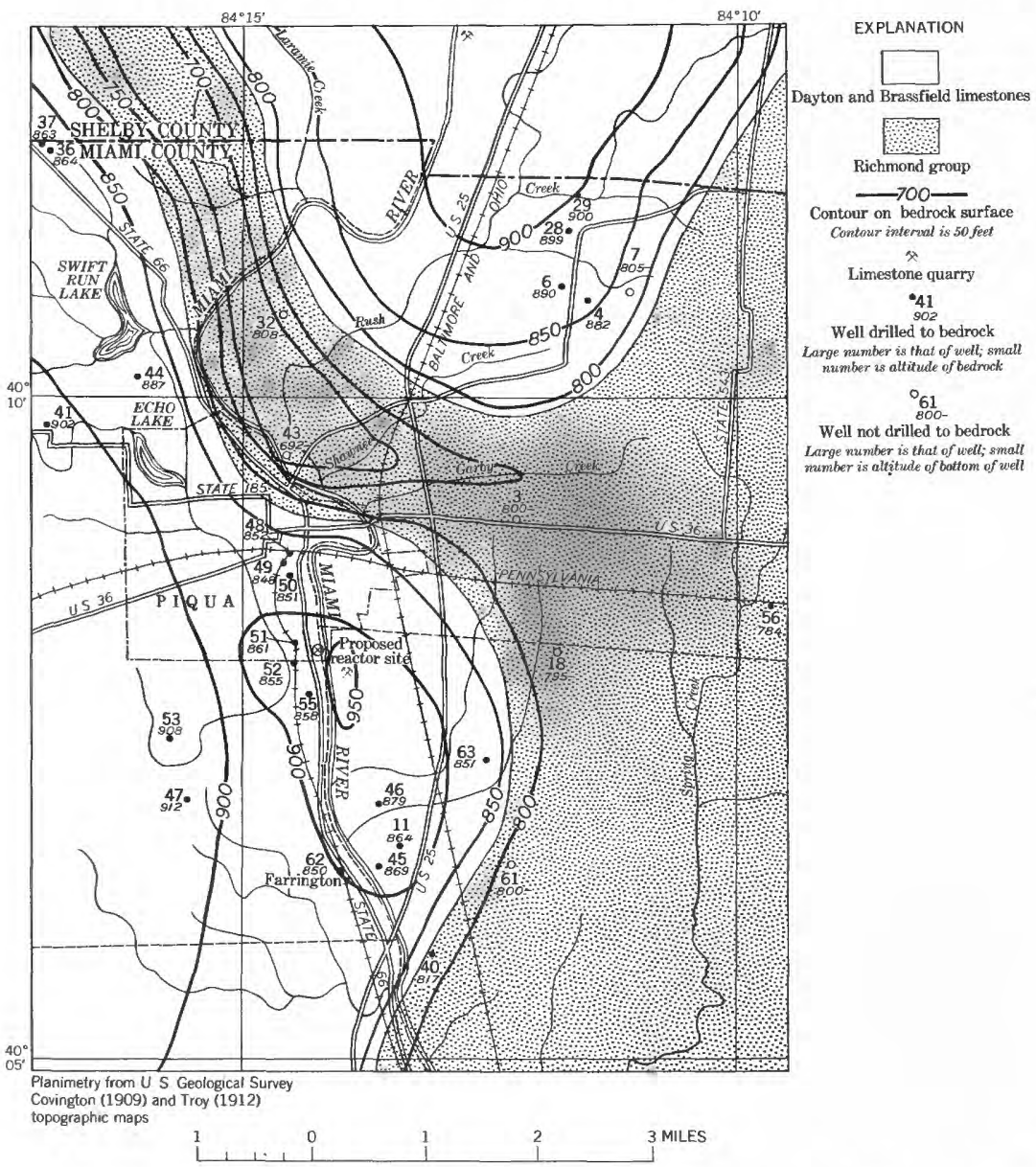

Figure 5.-Map of the Piqua area, Ohin, showing the distribution of the prineipal consolidated-rock units and approximate contours on the bedrock surface.

A generalized geologic section follows:

System

Rock unit

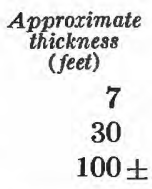

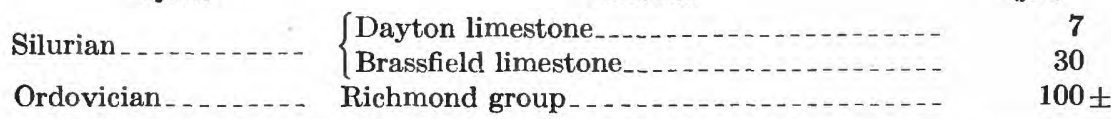

These strata lie on the west flank of the Cincinnati arch, near the crest, and dip northwest at a low angle, probably about 10 feet per mile. The altitude of the top of the Richmond group is approximately 826 feet at the proposed reactor site, where the Richmond lies beneath a few feet of the Brassfield limestone and alluvial deposits.

The Brassfield limestone and the Dayton limestone are exposed across the river from the proposed reactor site in a large quarry 
owned by the Armco Steel Corp. (figs. 6 and 7). The section was described by Stout (1941, p. 187) as follows:

Dayton limestone:

Dolomite, gray to buff, medium to massive layers, rather uniformly bedded, fine-grained, hard, few fossils . ....................

Shale, blue, irregular in thickness Brassfield limestone:

Limestone, hard, light to buff, parts pinkish tint, fossiliferous _....

Bedding plane, irregular with stylolites

Limestone, light to drab, mainly porous texture, grainy

Shale, irregular, with stylolites above.

Ft in

Limestone, light, hard, part porous, massive layers

Shale, greenish, with stylolites above

Limestone, light, massive, rather porous, crystalline, some fossils

Floor of quarry, limestone, gray, eartby.

The Richmond group consists principally of soft greenish-blue or blue-gray shale, interbedded with layers of hard limestone. The

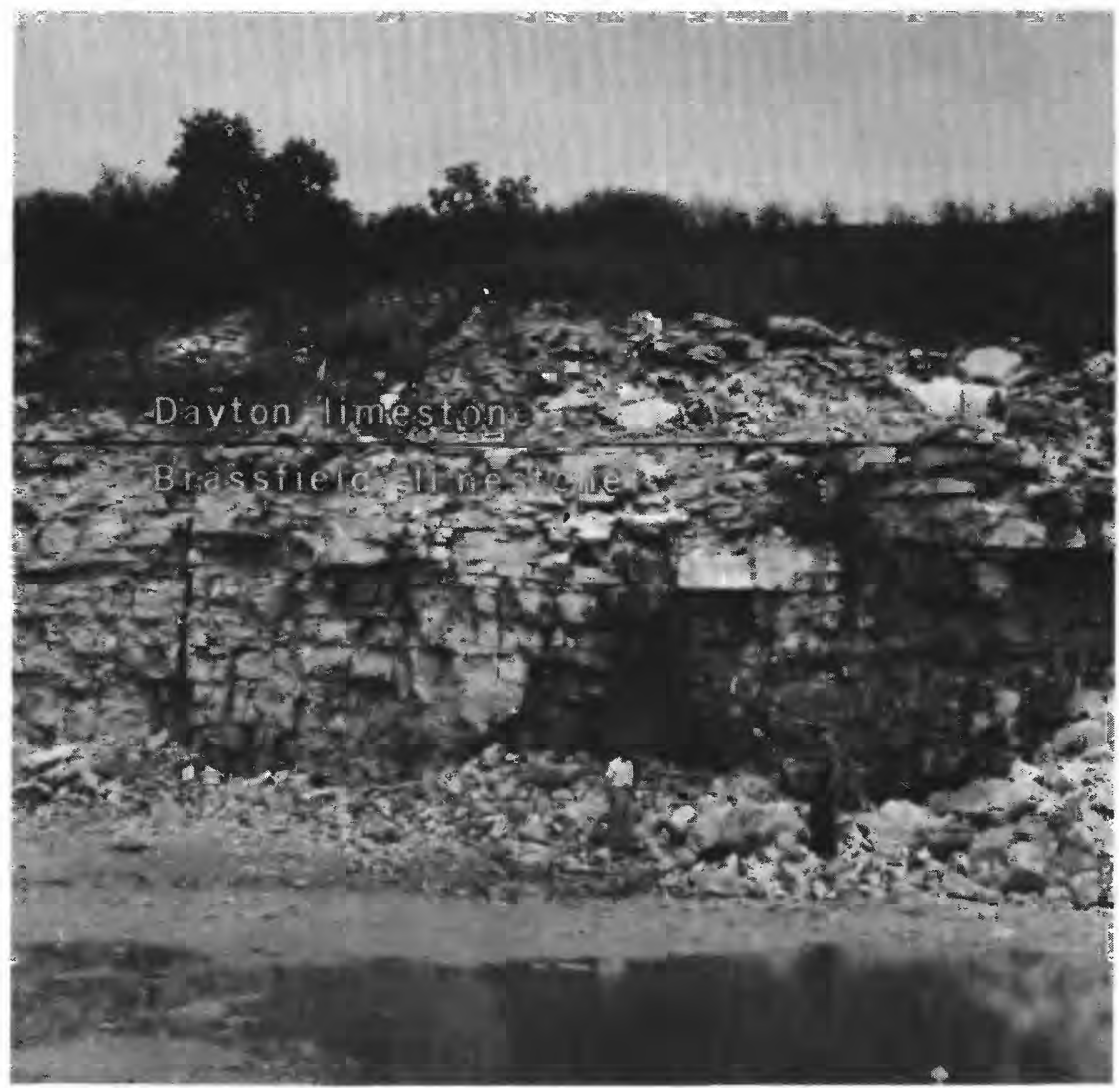

Figure 6.-Exposure of the Brassfield limestone and Dayton limestone in a quarry on the east bank of the Mlami River opposite the proposed reactor site. 


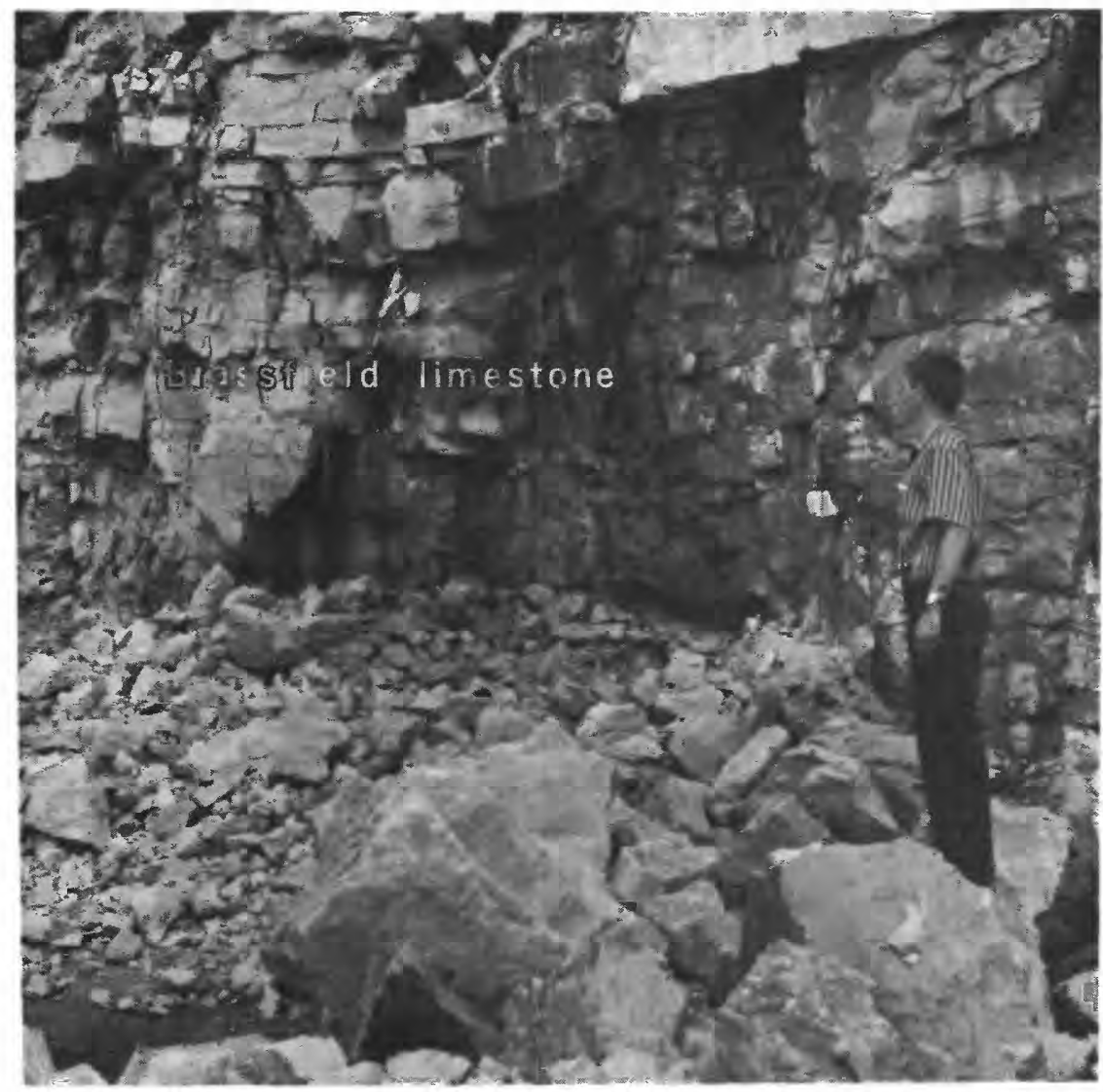

Figure 7.-Exposure of the Brassfield limestone in a quarry on the east bank of the Miami River opposite the proposed reactor site.

limestone layers average 1 to 5 inches in thickness and may make up 25 to 50 percent of the whole sequence. The Richmond group is similar lithologically to the shale units of the Maysville group which it overlies; the strata are differentiated on the basis of fossils. The aggregate thickness of the Richmond group and the underlying Maysville and Eden groups is a little more than 1,000 feet, according to the record of a well drilled for oil or gas in 1886 (Orton, 1888, p. 273). Shale of the Richmond group is very poorly permeable and generally marks the lower limit of ground-water supplies in the area.

Locally in western Ohio the uppermost unit of the Richmond group, the Elkhorn formation, is a soft greenish-blue puttylike shale, in which the limestone layers are few and thin. The Elkhorn formation is as much as 50 feet thick in places. At Piqua the lithologic character of the Richmond group was not determined, owing to lack of exposures. 
THE BEDROCK SURFACE

Figure 5 shows contours on the bedrock surface in the Piqua area, based largely on drillers' records of wells listed in table 1. East of Piqua the surface of the consolidated rocks forms a broad lowland east of and parallel to U.S. Highway 25. A narrow channel in the bedrock surface leads off northwestward from this lowland and underlies the area immediately northeast of Piqua. Such buried valleys were eroded by streams which drained the area prior to the Pleistocene glaciation, probably by northward-flowing tributaries of the ancient Teays River. The Teays River was the main stream of the principal preglacial drainage system in Ohio, and flowed northwestward across the State a few miles north of Piqua (Stout and others, 1943, p. 51-53; Norris and Spicer, 1958, fig. 16).

\section{GROUND WATER}

\section{SOURCE AND OCCURRENCE}

Ground water in the Piqua area has its source in local precipitation which percolates downward into the various aquifers and moves through these aquifers to points of discharge along the Miami River. In the areas immediately west and south of Piqua the Brassfield limestone is the principal source of water for farm and domestic wells, which generally yield as much as about $20 \mathrm{gpm}$. A much larger yield than this was reported at the Decker Packing Co., in the eastern part of Piqua, but the packing-company wells draw from both the limestone and an overlying sand and gravel bed. Where the Brassfield limestone has been thinned by erosion, as it is near the center of Piqua, it commonly yields less than $5 \mathrm{gpm}$ or is totally unproductive.

East, north, and northwest of Piqua, in the immediate vicinity of of the city, most wells tap sand and gravel aquifers interbedded in till. These aquifers generally range from 5 to 10 feet in thickness and underlie areas at least a few square miles in extent. The buried sand and gravel deposits show wide variation in character from place to place. Locally the deposits may consist of clean well-sorted coarse sand and gravel, ideally suited to the development of wells, but elsewhere they may be clayey, or made up chiefly of fine sand, making well development difficult or impractical. Because of these variable characteristics, wells located within a comparatively small area may be drilled to different depths and tap different sand and gravel aquifers. The elevations of water levels in such wells usually show correspondingly wide differences.

Generally the depth to water in wells in the Piqua area is roughly proportional to the depth of the well; that is, the deeper the well, the farther the water level is below the surface. Wells 7 and 8, located near each other about 3 miles northeast of Piqua, illustrate this 
point. Well 7 is 205 feet deep and the water level, in April 1955, was 97 feet below the surface. Well 8 is 142 feet deep and the water level in April 1955 was only 65 feet below the surface. Both wells are open in sand and gravel aquifers interbedded in till at the respective depths indicated by the wells.

The buried sands and gravels are sources adequate for farm and domestic wells, and locally these aquifers yield sufficient water for limited industrial use. Well 56, drilled for the F. S. Royster Guano Co., about 3 miles east of Piqua, yielded, during a 24-hour pumping test, $400 \mathrm{gpm}$ with a drawdown of 48 feet at the end of the test. This relatively high yield is not representative of these aquifers, however. Well 56 is screened in two aquifers, separated by 60 feet of till. Moreover, the water level in the well was still declining at a fairly rapid rate at the end of the test. Pumping in well 56 also produced a drawdown of 37 feet in well 21, nearly 3,000 feet away, which is evidence of the lateral continuity of these aquifers and the pronounced interference effects caused by pumping from them at a relatively high rate. No doubt a pumping rate in the magnitude of $100 \mathrm{gpm}$ would be more practical for well 56, and more representative of the water-yielding properties of the buried sand and gravel aquifers.

The most productive source of ground water in the Piqua area is the outwash sand and gravel deposits in the Miami River valley. This source is not used extensively at Piqua, however, because at most places within the city the deposits are thin or absent. About 1900 Piqua obtained its municipal supply from 14 wells (Stout and others, 1943, p. 465) drilled in outwash deposits in the north end of town, but the wells were abandoned in favor of the present surfacewater supply. At the present time a theater and one or two other commercial establishments have the only wells that tap the outwash deposits in Piqua.

The small use made of the valley-fill deposits at Piqua as sources of ground water is by no means representative of the importance of these aquifers generally in the Miami valley. Downstream from Piqua the outwash deposits are the source of about $200 \mathrm{mgd}$ (million gallons per day) of ground water, or nearly one-sixth the total pumped in the State. The pumping is most concentrated at Dayton, where pumpage at two plants, the Frigidaire Div., General Motors Corp. and the National Cash Register Co., totals more than $25 \mathrm{mgd}$. Closer to Piqua, the municipal wells at Troy, which range in depth from 45 to 84 feet, yield 350 to $1,500 \mathrm{gpm}$ each from sand and gravel deposits along the Miami River. Most wells drilled in the valleyfill deposits receive recharge by the induced infiltration of streamflow. Probably 75 to 90 percent of the water pumped from wells in the Miami valley has the river as its source. 


\section{A-14 STUDIES OF SITES FOR NUCLEAR ENERGY FACILITIES}

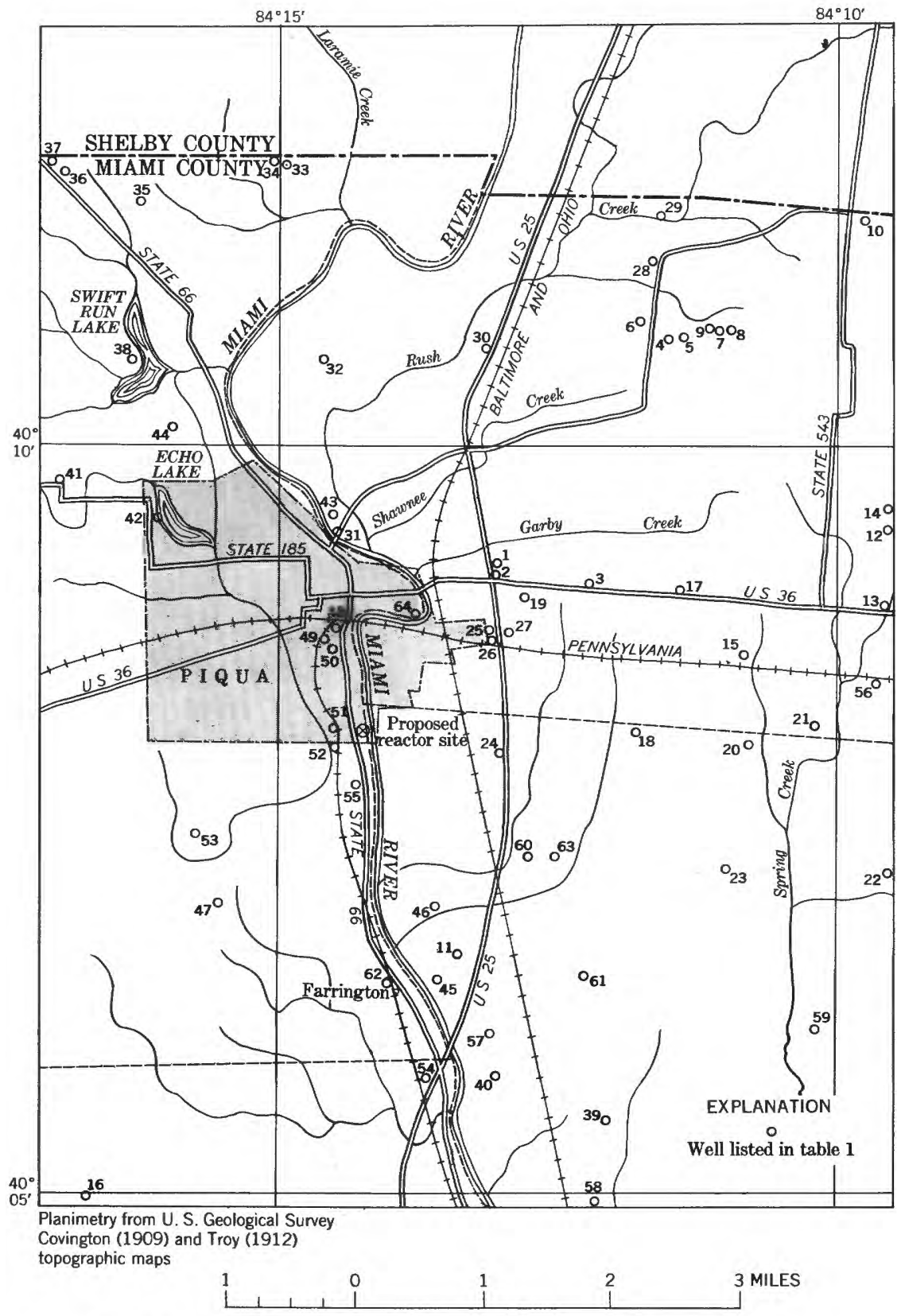

Figure 8.-Map of the Piqua area, Ohio, showing location of wells listed in table 1. 


\section{RATE OF GROUND-WATER FLOW}

The rate of ground-water movement in the Piqua area varies greatly from place to place, owing to the complexities of the geology and local hydrologic conditions, and it is difficult to estimate with confidence the rate of movement in most areas. Water movement in the limestone is along joints and cracks, commonly along the contact with shale of the underlying Richmond group. Where the limestone is thinly covered and lies close to the point of ground-water discharge, as it does in the area of the proposed reactor site, water probably moves at a comparatively high rate, probably measurable in feet or tens of feet per day.

Of importance with respect to hazards of contamination to downstream wells is the rate of ground-water movement through the outwash deposits in the Miami valley. Under natural hydraulic gradients in the Mad River valley near Dayton, where geologic conditions are similar to those in the Miami valley, W. C. Walton, of the U.S. Geological Survey (written communication, 1954), calculated the rate of ground-water flow through the outwash deposits as about 7 feet per day. In the Miami valley at a site near Hamilton, where pumpage from two ground-water collectors is in the magnitude of 15 mgd, G. D. Dove, of the U.S. Geological Survey (written communication, 1958), calculated the rate of movement of water through the outwash deposits from the river to the collectors as being as much as 13 feet per day. Hydraulic gradients at the site near Hamilton are not very steep, however, compared to the gradients at certain sites near Dayton-notably at the National Cash Register Co. plant, whose wells are very close to the stream-and it may be assumed that water moves through the outwash deposits in some areas at rates considerably greater than 13 feet per day.

The rate of travel of ground water into and through the sand and gravel aquifers interbedded with till on the uplands east and north of Piqua is conjectural. Water moves relatively slowly in the till, perhaps a few inches per day at most. The rate of movement would be many times greater once the water entered a buried sand and gravel lens, particularly in the vicinity of a pumped well.

The Richmond group, especially the clayey Elkhorn formation, transmits water very slowly. Tolman $(1937$, p. 219) reports that the effective velocity of water moving through clay under a hydraulic gradient of 1 percent is less than 0.004 foot per day. This figure is probably in the correct order of magnitude for the rate of movement of water through the Elkhorn formation.

The direction of movement of subsurface water at the reactor site is a matter of some uncertainty. The land-surface altitude is about 858 feet. The static level of ground water on September 3, 1958, in 
borings drilled for foundation exploration at the reactor site, was about 846 feet. The river is about 200 feet to the east, and its level was about 837 feet. There is a dam in the river about 300 feet upstream from the reactor site, and the river level above the dam was about 845 feet. These measurements suggest that ground water is flowing from the site toward the river. An element of uncertainty results from two unknowns, however:

1. The effect of the buried Miami-Erie Canal: the reactor site is on the old Miami-Erie Canal. There is evidence indicating that the old canal bottom may still be relatively watertight and may perch water above the water table. If so, the levels measured in the foundation borings may have been indicative of a perched body of water along the old canal.

2. The effect of pumping from wells to the northwest and southwest within about a thousand feet from the site: One commercial well has a reported capacity of $12 \mathrm{gpm}$ (Piqua Granite Co.) and an undetermined but small number of domestic wells pump water from the same limestone formation that underlies the reactor site. Drillers' records for two wells of measurements made at the time the wells were drilled show both static and pumping levels to be above river level, but present levels are not known.

\section{SURFACE WATER}

The only appreciable use of surface water in the Piqua area takes place upstream from the proposed reactor site. The municipal supply of Piqua comes from the Miami River and two impounding reservoirs (Swift Run Lake and Echo Lake), and the main pumping station is 2 miles north of town. Municipal water use averages about $3 \mathrm{mgd}$. The Piqua municipal powerplant circulates for cooling purposes as much as $44 \mathrm{mgd}$ from the Miami River. The plant intake and discharge are immediately upstream from the proposed reactor site.

A 3-year record (1915-17) of streamflow at Piqua is listed in table $3 \mathrm{~A}$. This record is too short to be very meaningful, however, and is included only as supplemental data. The most significant streamflow data collected in the Piqua area come from gaging stations on Loramie Creek at Lockington (tables 2A, 3B, and 4A) and on Miami River at Sidney, about 10 miles upstream from Piqua (tables $2 B, 3 \mathrm{C}$, and 4B). The drainage area of Loramie Creek above Lockington is 261 square miles, and the drainage area of the Miami River above Sidney is 545 square miles; the area gaged, therefore, is 806 square miles, only 36 square miles less than the total drainage area above Piqua. The records from Lockington and Sidney taken together, therefore, give a close approximation of flow at Piqua. 
The lowest daily flow recorded at Sidney, since the beginning of record, in February 1914, was $8.0 \mathrm{cfs}$ (cubic feet per second) on September 23, 1935. The minimum daily flow recorded at Lockington since October 1915 was $2.4 \mathrm{cfs}$, on August 18, 1931, and September 19-21, 1936. Thus, the daily flow at Piqua, under extreme drought conditions, might be expected to be in the magnitude of 10 to $15 \mathrm{cfs}$, or between 6 and $10 \mathrm{mgd}$. The flow equaled or exceeded at Piqua 90 percent of the time, based on the records from Lockington and Sidney, is in the magnitude of $53 \mathrm{cfs}$, or about $35 \mathrm{mgd}$.

Two lakes in the Miami drainage basin upstream from Piqua have a decided effect on streamflow. Lake Loramie (capacity 13,000 acre-feet, area 70 square miles), on Loramie Creek in the western part of Shelby County, and Indian Lake (capacity 45,900 acre-feet, area 110 square miles), on the Miami River in the northwest corner of Logan County (fig. 2), act as reservoirs and tend to stabilize the dry-weather flow of the two streams. Gate openings are seldom changed on either reservoir.

Inasmuch as the proposed reactor site is on the flood plain of the Miami River, the frequency and magnitude of floods merit consideration. Figure 9 shows the probable recurrence interval of floods on the Miami River based on the records of the U.S. Weather Bureau gaging station at Ash Street, Piqua, about 1 $\frac{1}{2}$ miles upstream from the reactor site, from 1930 to 1959 . The approximate altitude of the site is 858 feet. Because the site is $1 \frac{1}{2}$ miles downstream from the gaging station, the altitude of flood crests at the site is several feet lower.

The 1913 flood, the most serious on record, reached an altitude of 873 feet at Main Street, three-quarters of a mile upstream from the Ash Street gaging station and 21/4 miles upstream from the reactor site. Lockington Dam, completed in 1922 on Loramie Creek, would reduce by several feet the height of a flood comparable to that of 1913 flood in Piqua. Even considering the reduction, a flood of the 1913 magnitude would be on the order of twice the 1959 flood discharge. The site requires protection, perhaps a levee, against rare floods.

\section{CHEMICAL QUALITY OF WATER}

No analyses of ground-water samples in the Piqua area are available. Table $5 A$ shows several analyses from wells drilled in Montgomery County into aquifers similar to those in the Piqua area. These analyses are believed to be characteristic of water that would be found in the various aquifers at and near Piqua. Such water is generally hard and high in iron content. As a general rule the iron content increases with depth, other things being comparable. (See wells 184 and 197 , table $5 A$.) 


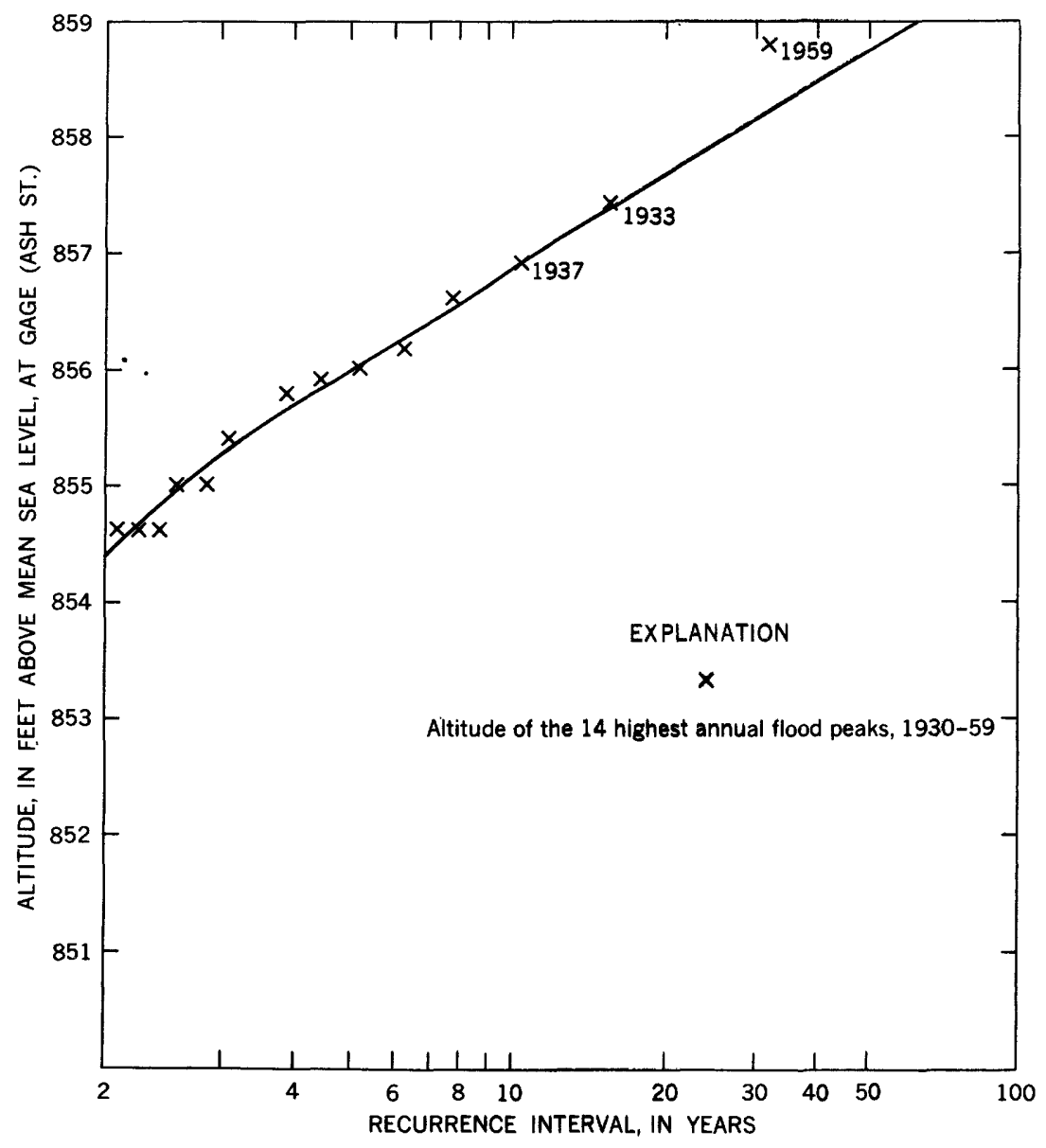

Figure 9.-Flood-frequency diagram, Miami River at Piqua, Ohio, 1930-69.

Table $5 B$ shows analyses of three samples from streams in the vicinity of Piqua. The samples from Miami River at Sidney and Loramie Creek at Lockington were taken upstream from the proposed reactor site, and the sample from Miami River near Troy was taken downstream from the reactor site.

Table $5 C$ shows analyses of water from three public supplies near Piqua. The Piqua supply is taken from the Miami River above the proposed site. The Troy and Vandalia supplies come from wells which are recharged by infiltration from the Miami River below the proposed reactor site.

The analyses shown in tables $5 A$ and $5 B$ were made by the U.S. Geological Survey. Those shown in table $5 C$ were made by the Ohio Department of Health. 
It may be of interest that Miami River at Venice, 70 miles downstream from Piqua, was found in June 1958 to contain $0.7 \mathrm{ppm}$ strontium, a relatively high concentration for a stream water. No other analyses for strontium have been made in or near the area under investigation.

Besides the data presented herein, the Geological Survey has a daily sediment record at Dayton for the period October 1951 to September 1953, and a record of periodic and daily determinations of chemical quality of Miami River at Dayton for the period July 1946 to September 1948.

\section{EARTHQUAKE ACTIVITY}

At least 11 earthquakes have been recorded whose epicenters were in the State of Ohio. According to Heck (1947), 6 of these shocks had an intensity of 6 or greater on the Rossi-Forel scale (see table below), and 5 of these had epicenters in the vicinity of latitude $40^{\circ}$ to $41^{\circ} \mathrm{N}$., longitude $84^{\circ} \mathrm{W}$., not far from Piqua.

\section{Earthquakes in Ohio}

[After Heck, 1947]

\begin{tabular}{|c|c|c|c|c|c|}
\hline \multirow{2}{*}{ Date } & \multirow{2}{*}{ Hour } & \multicolumn{2}{|c|}{ Locality } & \multirow{2}{*}{$\begin{array}{c}\text { Area felt } \\
\text { (square miles) }\end{array}$} & \multirow{2}{*}{$\begin{array}{c}\text { Intensity } \\
\text { (Rossi- } \\
\text { Forel } \\
\text { scale) }\end{array}$} \\
\hline & & Lat. $\mathrm{N}$. & Long. w. & & \\
\hline 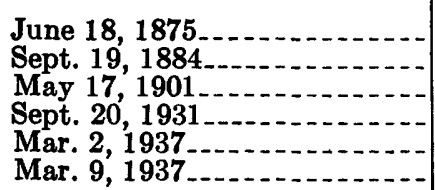 & $\begin{array}{l}0743 \\
1414 \\
0100 \\
1705 \\
0948 \\
0045\end{array}$ & $\begin{array}{l}40.2 \\
40.7 \\
39.3 \\
40.2 \\
40.7 \\
40.6\end{array}$ & $\begin{array}{l}\text { 84. } 0 \\
\text { 84. } 1 \\
\text { 82. } 5 \\
\text { 84. } 3 \\
\text { 84. } 0 \\
\text { 84. } 0\end{array}$ & $\begin{array}{r}40,000 \\
125,000 \\
7,000 \\
40,000 \\
90,000 \\
150,000\end{array}$ & $\begin{array}{r}6-7 \\
6 \\
6 \\
8 \\
8 \\
8\end{array}$ \\
\hline
\end{tabular}

The earthquakes of March 2 and 9, 1937 (Rouse and Priddy, p. 25-27), both had their epicenters near the village of Anna, 17 miles north of Piqua. These tremors were felt in most of Ohio, but damage was apparently restricted to a radius of about 4 miles from the epicenters. Chimneys toppled, windows shattered, and cracks appeared in the walls of houses at Anna. A school and two churches were severely damaged. The walls of the school were so severely cracked that the building had to be condemned.

No damage from these quakes was reported in Piqua or anywhere else in the Miami valley, according to the Dayton Journal and the Sidney Daily News. Many Miami valley residents were awakened by the quake of March 9, which occurred at 12:45 a.m. Ominous rumbling was reported by some residents of Dayton.

The cause of these earthquakes has never been established. Plausible hypotheses are that the quakes were due to collapse of limestone 
caverns about 25 miles northeast of Piqua or that they were the result of movement along the Bowling Green fault.

The Bowling Green fault can be traced from the Michigan line near Toledo southward to Kenton in Hardin County, where it is lost under a thick cover of glacial drift. A continuation of the trace of this fault passes through the east edge of Logan and Champaign Counties, about 30 miles east of Anna and Piqua. The relation of this fault to earthquake activity has not been established.

\section{SUMMARY AND CONCLUSIONS}

The proposed reactor site is on the west bank of the Miami River at Piqua, Ohio, about 30 miles upstream (north) from Dayton, Ohio. The estimated daily flow of the river at Piqua under drought conditions would be 10 to $15 \mathrm{cfs}$; the flow expected to be equaled or exceeded 90 percent of the time is about $53 \mathrm{cfs}$.

The site is underlain by horizontally bedded, highly fractured limestone about 25 feet thick which is underlain by shale interbedded with limestone of undetermined thickness. The site is, in part, on the now-abandoned and buried Miami-Erie Canal, which here paralleled the river. Hence, the surficial material, as much as 9 feet thick, consists of dumped rock used to fill in the canal. In the vicinity of the site, and for a mile or two downstream along the river, the natural unconsolidated overburden (glacial drift) is thin or absent, and the limestone is at or near the land surface. However, thick and extensive deposits of glacial till overlie the limestone to both the east and the west of the site. At the site and for about 2 miles downstream, the flood plain of the Miami River is relatively narrow; beginning about 2 miles downstream and continuing to Dayton and beyond, the flood plain of the river is considerably wider and is underlain by permeable sand and gravel deposits.

The Piqua municipal water supply is pumped from the Miami River upstream from the reactor site. Downstream from the site virtually all water used for municipal and industrial purposes is pumped from wells that tap the sand and gravel underlying the river flood plain. Total daily pumpage from such wells is estimated to average 100 million gallons, most of it pumped in or near Dayton. Of particular importance is the estimate that 75 percent or more of the water pumped from wells is derived from the river by induced infiltration to the various well fields. The nearest downstream well field open to recharge from the river is that of the municipal supply of Troy, about 8 miles downstream. Pumpage at Troy is on the order of 1 or $2 \mathrm{mgd}$. 
Owing to possible effects of nearby ground-water pumping and to the presence of the buried Miami-Erie Canal, the direction of ground-water movement in the vicinity of the site is unknown.

What, then, might happen to a liquid spilled on the land surface at the reactor site? According to the soil condition at the time of the spill, the volume of liquid spilled, the rate of spill, and other factors:

1. The liquid might be absorbed by the soil in whole or in part. However, the soil and unconsolidated overburden are quite thin and cannot be dependend on for significant hold-up of a spilled contaminant.

2. The liquid might flow overland to the river some 200 feet away.

3. The liquid might percolate down to the water table and thence move with ground water to the river. Because the aquifer is a fractured limestone, it would not be prudent (without evidence to the contrary) to depend on a time of travel of more than several hours before the liquid reached the river. However, the relatively impermeable fill in the old canal bed might act to delay movement of the contaminant to the river.

4. The liquid might percolate down to the water table and thence move with ground water westward toward one or more pumped wells. The evidence available to the authors, however, favors the previous assumption-that is, that ground water at the site moves to the river and away from the wells. But even if this is true for existing conditions, there is no guarantee that future development of ground-water supplies in the immediate vicinity could not reverse the natural gradient at the reactor site.

In short, the on-site retention by the natural environment of a spilled liquid contaminant cannot be depended on to be more than a matter of a few hours, or at most a few tens of hours. The most probable assumption is that the liquid would enter the river either by overland flow or by subsurface flow, or by both. Once in the river it would, of course, move downstream with the river water. Dilution and time of travel would depend on river conditions at the time. Travel time to Dayton, which would vary greatly with discharge, might range from a few hours to several days. Where river water recharges a subjacent aquifer the rate of flow through the aquifer is estimated to range from a few feet to several tens of feet per day. Detailed time of travel and dilution computations for a "slug" of contamination to individual well fields cannot be made on the basis of presently available information. 


\section{REFERENCES CITED}

Conrey, G. W., Paschall, A. H., and Burrage, E. M., 1934, A key to the soils of Ohio: Ohio State Univ. Eng. Expt. Sta. Circ. 44, 51 p., 1 fig., 15 tables. Cross, W. P., and Hedges, R. E., 1959, Flow duration of Ohio streams: Ohio Dept. Nat. Resources, Div. Water Bull. 31, 152 p., 22 pls., 219 tables.

Heck, H. H., 1947, Earthquake history of the United States, pt. 1, Continental United States (exclusive of California and western Nevada) and Alaska: U.S. Coast and Geod. Survey Serial 609, rev. ed.

Lamar, W. L., and Schroeder, M. E., 1951, Chemical character of surface waters of Ohio: Ohio Dept. Nat. Resources, Div. Water Bull. 23, 100 p., 3 pls.

Norris, S. E., Cross, W. P., and Goldthwait, R. P., 1948, The water resources of Montgomery County, Ohio: Ohio Dept. Nat. Resources, Div. Water Bull. 12, 83 p., 48 pls.

Norris, S. E., and Spicer, H. C., 1958, Geological and geophysical study of the preglacial Teays Valley in west-central Ohio: U.S. Geol. Survey WaterSupply Paper 1460-E, 33 p., 2 pls., 1 fig.

Ohio Department of Health, 1952, Analyses of municipal water supplies in Ohio: Ohio Dept. Health brochure (no text), 8 tables.

Orton, Edward, 1888, Economic geology: Ohio Geol. Survey, v. 6, 831 p.

Rouse, J. T., and Priddy, R. R., 1937, Recent earthquakes in western Ohio: Ohio Jour. Sci., v. 38, no. 1, p. 25-35.

Stout, Wilber, 1941, Dolomites and limestones of western Ohio: Ohio Geol. Survey Bull. 42, 468 p., 2 tables, map.

Stout, Wilber, Ver Steeg, Karl, and Lamb, G. F., 1943, Water in Ohio: Ohio Geol. Survey Bull. 44, 694 p., 1 table, 8 maps.

Tolman, C. F., 1937, Ground water: New York, McGraw-Hill, 593 p. 
BASIC DATA 
A-24 STUDIES OF SITES FOR NUCLEAR ENERGY FACILITIES

\begin{tabular}{|c|c|c|c|c|c|}
\hline \multirow[t]{2}{*}{ 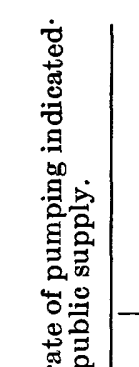 } & & & \multicolumn{3}{|c|}{ 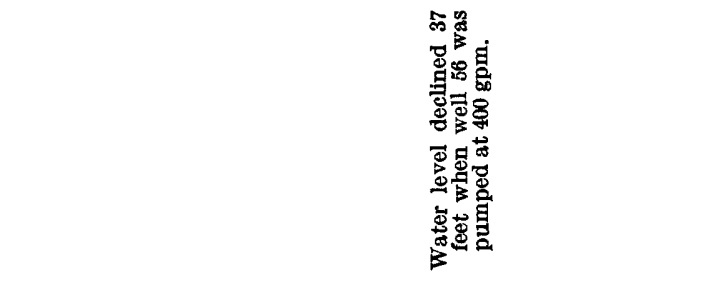 } \\
\hline & \multicolumn{2}{|c|}{$\stackrel{\circ}{\circ}$} & 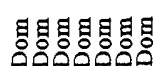 & 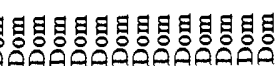 & 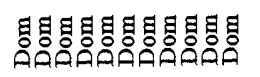 \\
\hline 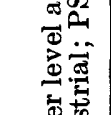 & \multicolumn{2}{|c|}{ 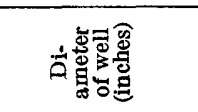 } & Hale & 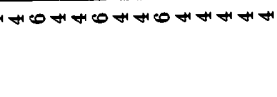 & 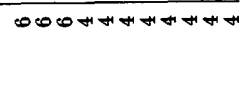 \\
\hline 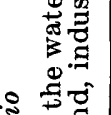 & \multirow{2}{*}{ 胥 } & 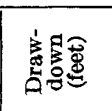 & NOール & : & 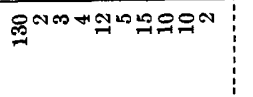 \\
\hline 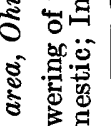 & & 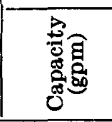 & 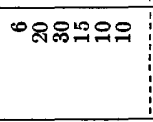 & 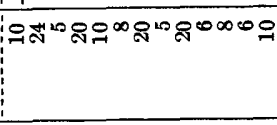 & 구ำ \\
\hline 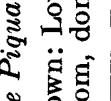 & \multirow{2}{*}{ 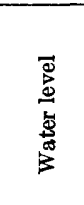 } & 递 & 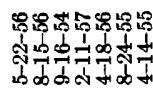 & 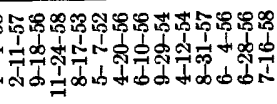 & 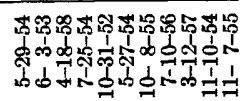 \\
\hline 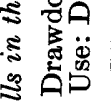 & & 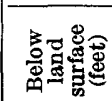 & 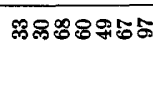 & 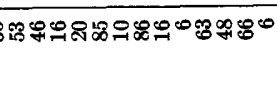 & இ용ำ \\
\hline & \multirow{2}{*}{ 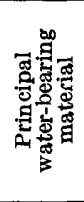 } & 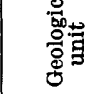 & 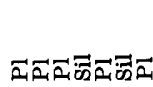 & 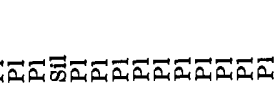 & 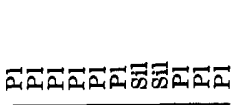 \\
\hline & & 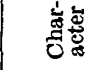 & 000000002902002 & $\cos \theta 00$ & \multirow{2}{*}{ 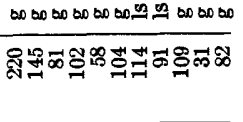 } \\
\hline & \multicolumn{2}{|c|}{ 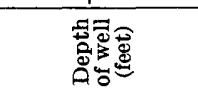 } & 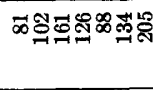 & 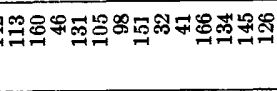 & \\
\hline 承 & \multicolumn{2}{|c|}{ 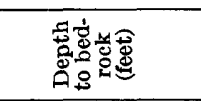 } & $\begin{array}{ll:l} & 0 \\
& 8 & 8 \\
\end{array}$ & 9 & 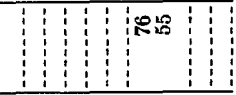 \\
\hline 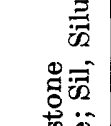 & \multicolumn{2}{|c|}{ 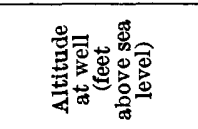 } & 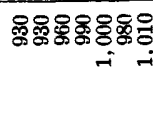 & 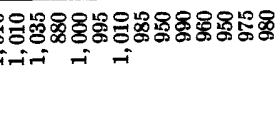 & 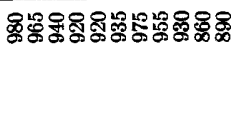 \\
\hline 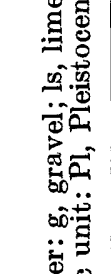 & \multicolumn{2}{|r|}{ 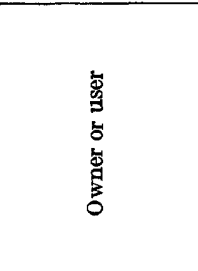 } & 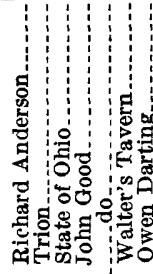 & 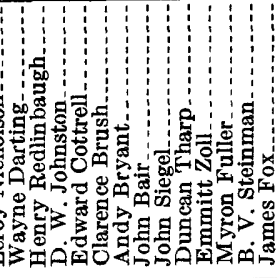 & 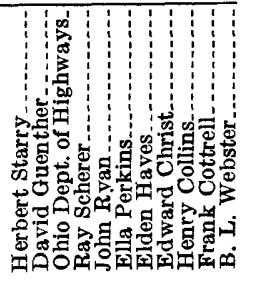 \\
\hline 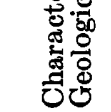 & \multicolumn{2}{|c|}{ 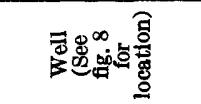 } & tenestroson & 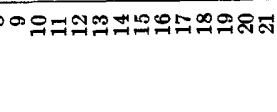 & 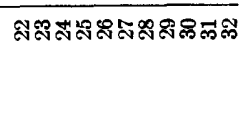 \\
\hline
\end{tabular}




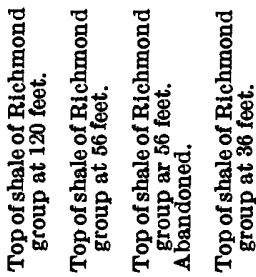

लं

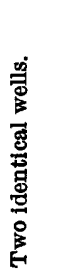

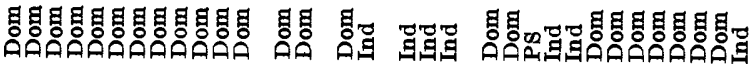

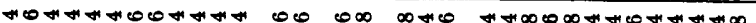

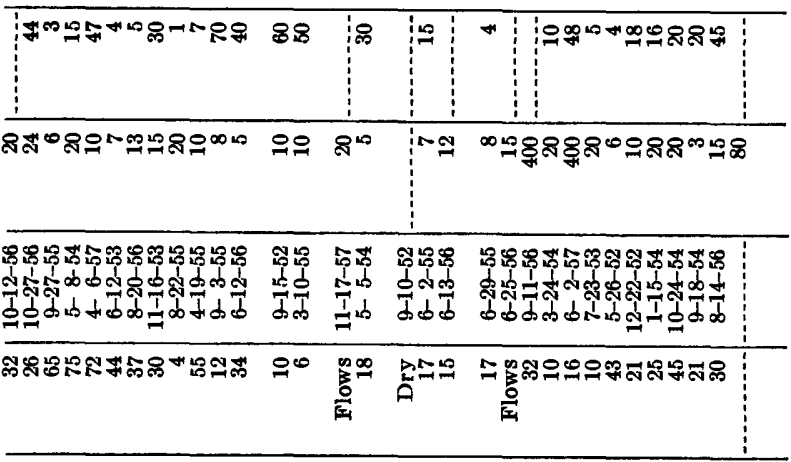

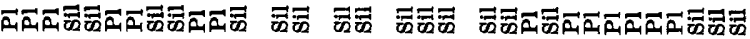

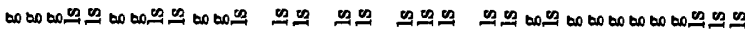

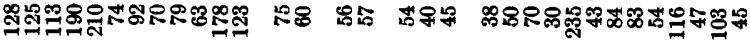

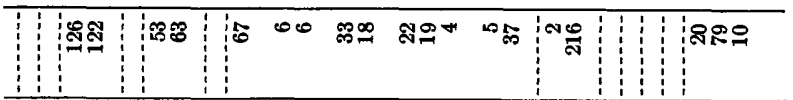

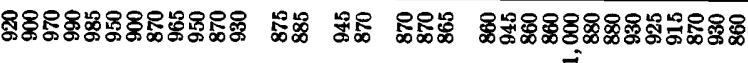

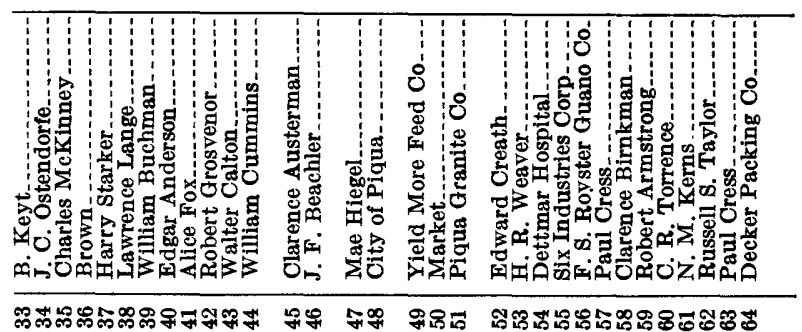




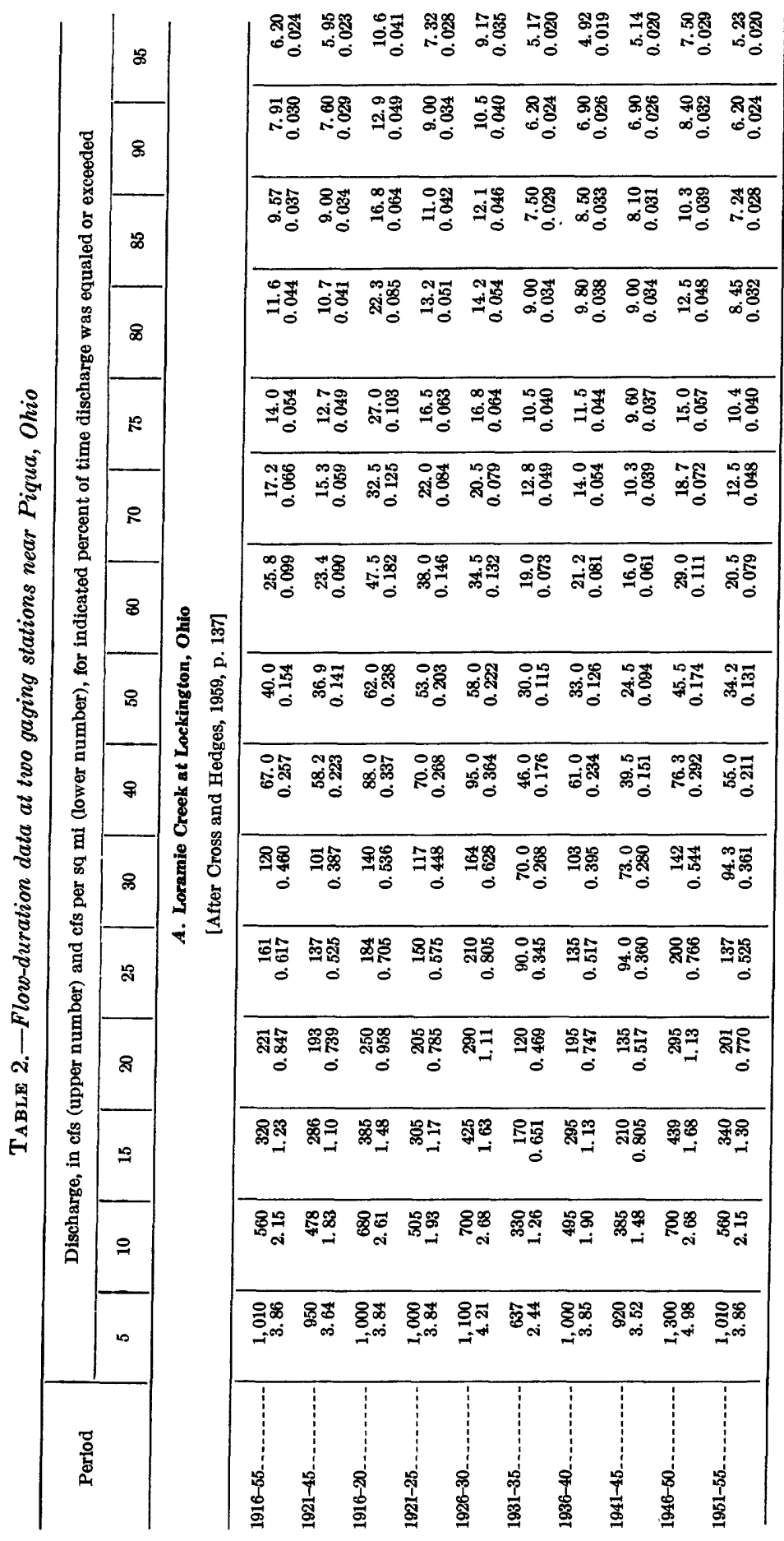




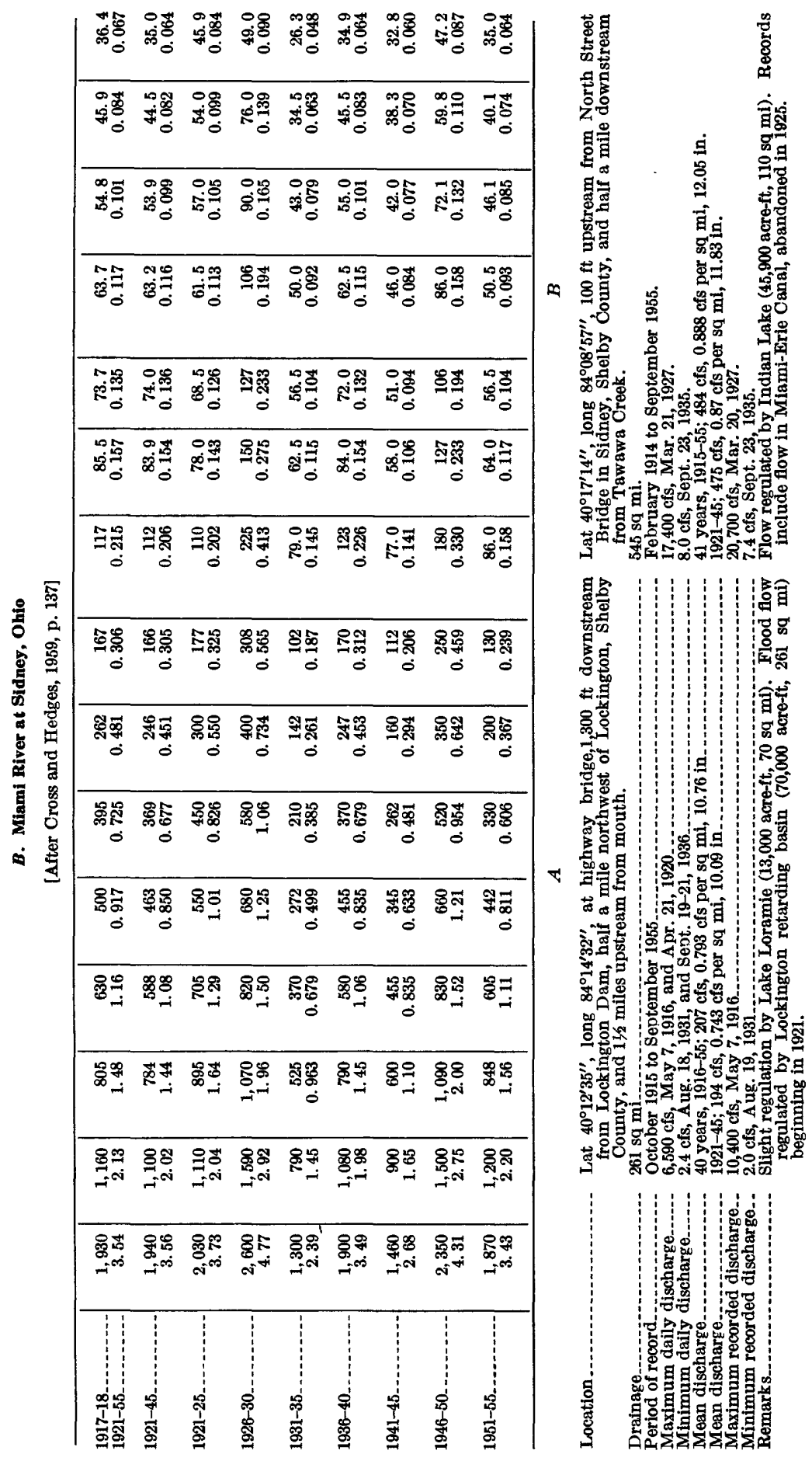


A-28. STUDIES OF SITES FOR NUCLEAR ENERGY FACILITIES

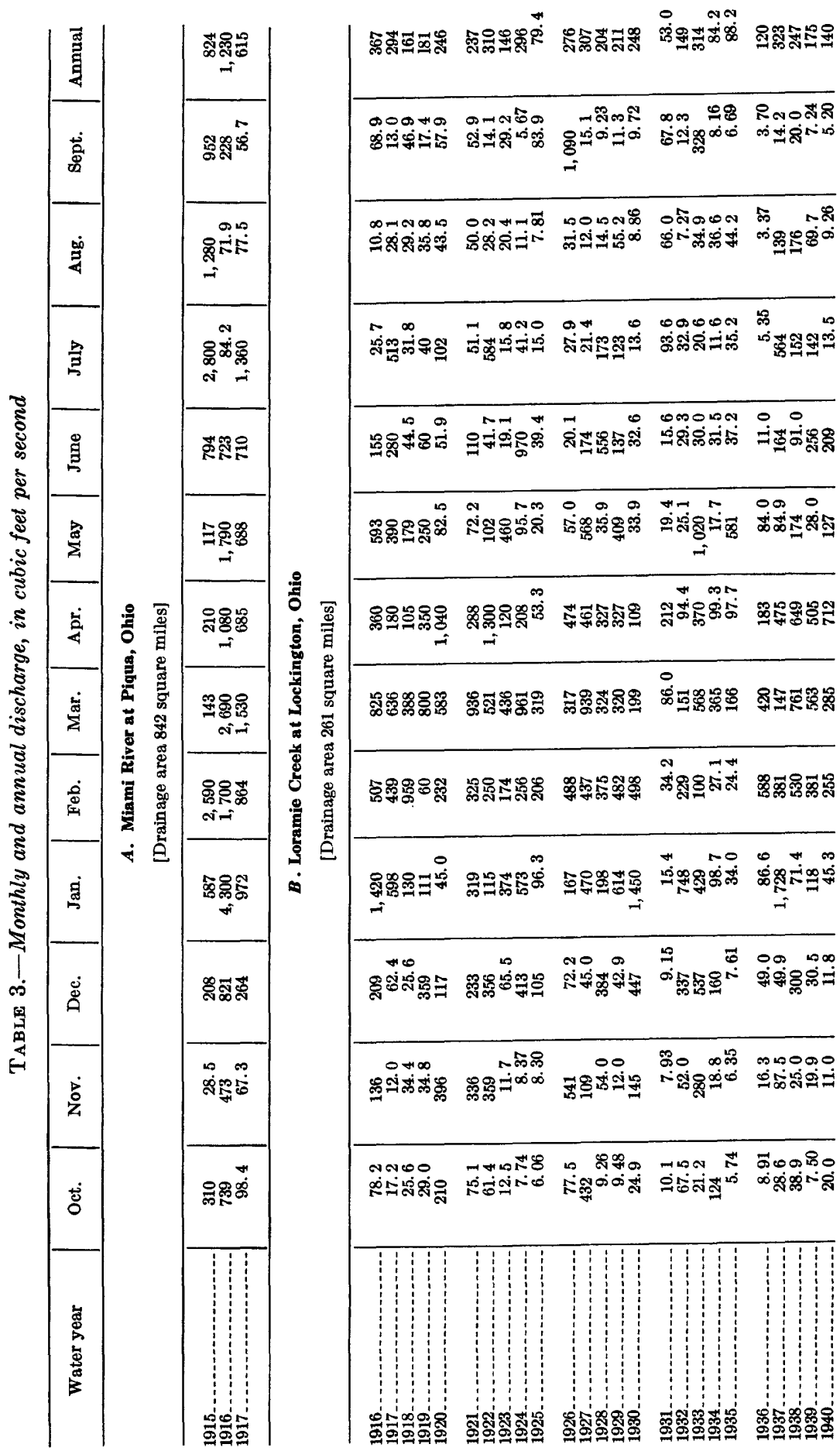


$\pi$

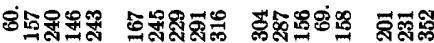

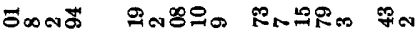

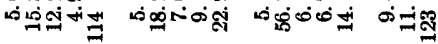

N

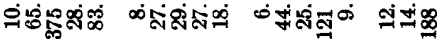

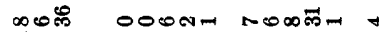

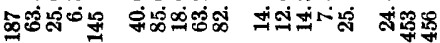

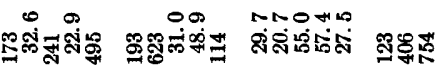
$-$

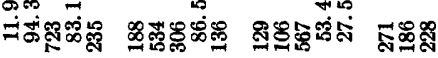

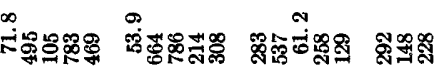

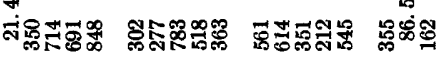

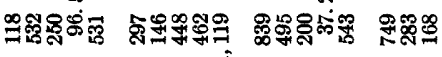

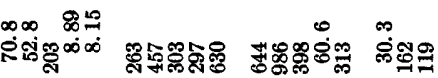

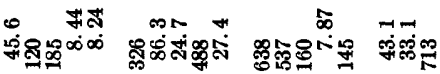

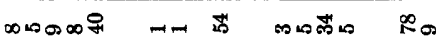

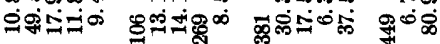

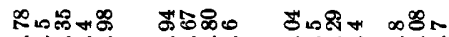

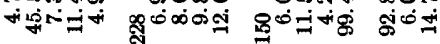

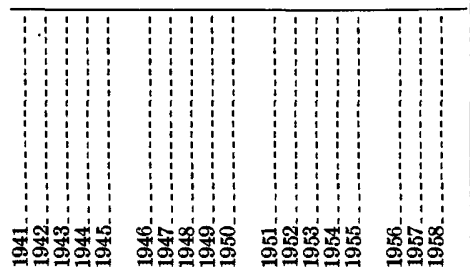

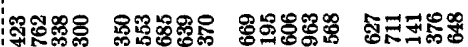

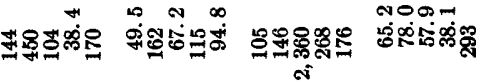

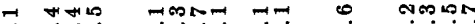

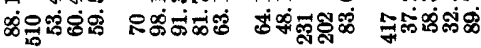

ம்

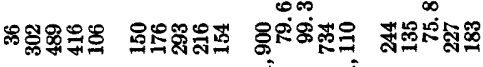

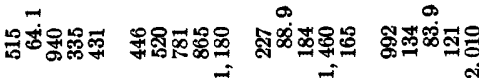

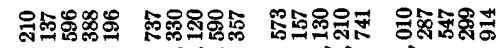
$\rightarrow$ Nin $\rightarrow-i$

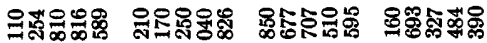

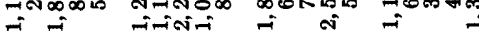

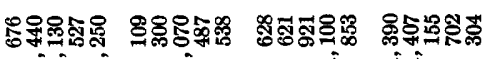
$\because=-\rightarrow$ 为옹 $\rightarrow \quad \rightarrow \rightarrow-i$

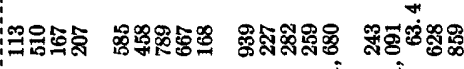

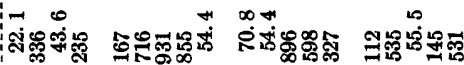
no hI

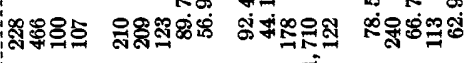

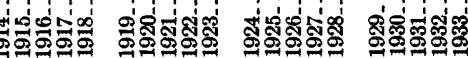


A-30 STUdiES OF SITES FOR NUCLEAR ENERGY FACILITIES

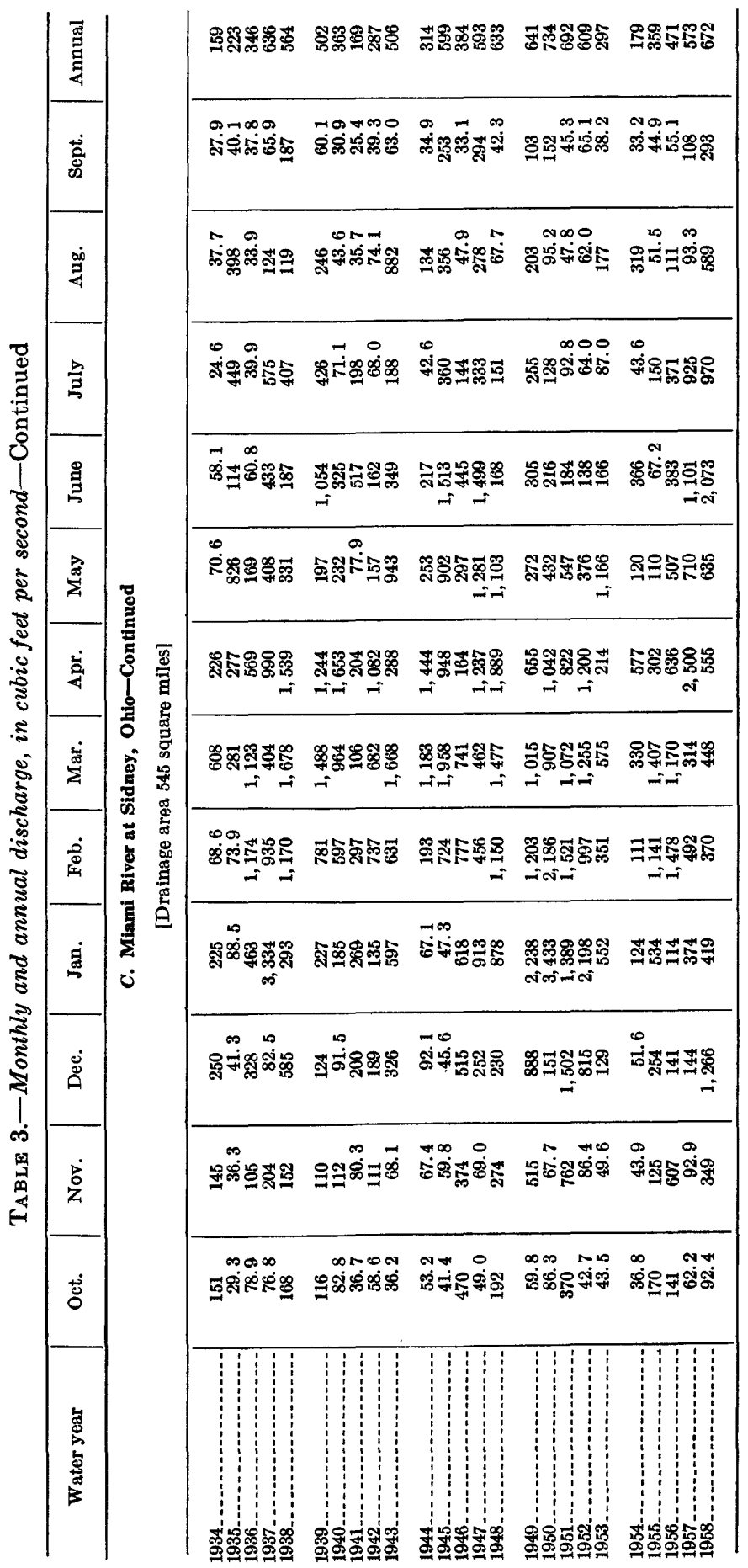


TABLE 4.-Momentary maximum, minimum daily, and annual mean discharge, in cubic feet per second

\begin{tabular}{|c|c|c|c|c|c|c|}
\hline \multirow{3}{*}{ Year } & \multirow{3}{*}{$\begin{array}{l}\text { Water- } \\
\text { supply } \\
\text { paper }\end{array}$} & \multicolumn{4}{|c|}{ Water year ending Sept. 30} & \multirow{3}{*}{$\begin{array}{l}\text { Mean for } \\
\text { calendar } \\
\text { year }\end{array}$} \\
\hline & & \multicolumn{2}{|c|}{ Momentary maximum } & \multirow{2}{*}{$\underset{\text { daily }}{\text { Minimum }}$} & \multirow{2}{*}{ Mean } & \\
\hline & & Amount & Date & & & \\
\hline
\end{tabular}

A. Loramie Creek at Lockington, Ohio

\begin{tabular}{|c|c|c|c|c|c|c|}
\hline $\begin{array}{l}1916 \\
1917 \\
1918 \\
1920 \\
1921 \\
1922 \\
1923 \\
1925 \\
1927 \\
1928 \\
1930 \\
1931 \\
1933 \\
1934 \\
1936 \\
1937 \\
1938 \\
1940 \\
1941 \\
1942 \\
1943 \\
1950\end{array}$ & $\begin{array}{r}\mathbf{5 2 3}, \mathbf{9 2 3} \\
\mathbf{5 2 3} \\
\mathbf{5 2 3} \\
\mathbf{5 2 3} \\
\mathbf{5 2 3} \\
\mathbf{5 2 3} \\
\mathbf{5 4 3} \\
\mathbf{5 6 3} \\
\mathbf{5 8 3} \\
\mathbf{6 0 3} \\
\mathbf{6 2 3} \\
\mathbf{6 4 3} \\
\mathbf{6 6 3} \\
\mathbf{6 8 3} \\
\mathbf{6 9 8} \\
\mathbf{7 1 3} \\
\mathbf{7 2 8} \\
\mathbf{7 4 3} \\
\mathbf{7 5 8} \\
\mathbf{7 8 3} \\
803 \\
\mathbf{8 2 3} \\
\mathbf{8 5 3} \\
\mathbf{8 7 3} \\
\mathbf{8 9 3} \\
\mathbf{9 2 3} \\
\mathbf{9 5 3} \\
\mathbf{9 7 3} \\
\mathbf{1 0 0 3} \\
\mathbf{1 0 3 3} \\
\mathbf{1 0 5 3} \\
\mathbf{1 0 8 3} \\
\mathbf{1 1 1 3} \\
\mathbf{1 1 4 3} \\
\mathbf{1 1 7 3} \\
\mathbf{1 2 0 5} \\
\mathbf{1 2 3 5} \\
\mathbf{1 2 7 5} \\
\mathbf{1 3 3 5} \\
1385 \\
\mathbf{1 4 3 5} \\
\mathbf{1 5 0 5}\end{array}$ & 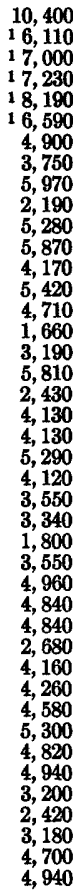 & 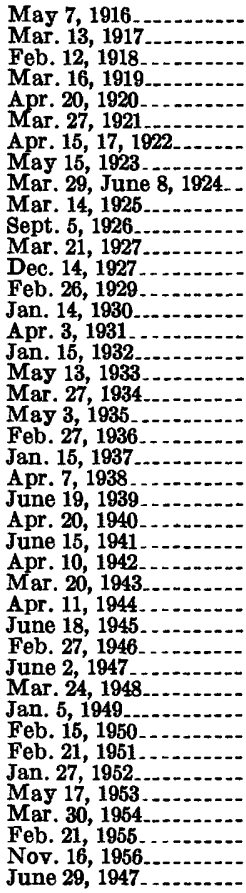 & $\begin{array}{l}5 \\
12 \\
11 \\
24 \\
32 \\
12 \\
8 \\
5 \\
5 \\
9.5 \\
8.8 \\
8 \\
8 \\
7.2 \\
2.4 \\
4.1 \\
5.8 \\
3.4 \\
3.8 \\
2.4 \\
7.1 \\
8.0 \\
5.2 \\
3.8 \\
2.6 \\
2.8 \\
5.4 \\
3.7 \\
4.4 \\
4.4 \\
4.3 \\
5.8 \\
6.1 \\
7.4 \\
4.5 \\
4.7 \\
4.0 \\
3.8 \\
3.5 \\
3.8 \\
3.0\end{array}$ & $\begin{array}{c}367 \\
264 \\
161 \\
181 \\
246 \\
237 \\
310 \\
146 \\
296 \\
79.4 \\
276 \\
307 \\
204 \\
211 \\
248 \\
53.0 \\
149 \\
314 \\
84.2 \\
88.2 \\
120 \\
323 \\
247 \\
175 \\
140 \\
60.4 \\
157 \\
240 \\
146 \\
243 \\
167 \\
245 \\
229 \\
291 \\
316 \\
304 \\
287 \\
156 \\
69.4 \\
158 \\
201 \\
231\end{array}$ & $\begin{array}{c}340 \\
264 \\
190 \\
205 \\
239 \\
248 \\
253 \\
175 \\
270 \\
126 \\
268 \\
296 \\
171 \\
257 \\
198 \\
89.3 \\
181 \\
269 \\
60.1 \\
92.8 \\
127 \\
340 \\
221 \\
174 \\
142 \\
73.3 \\
156 \\
225 \\
145 \\
297 \\
121 \\
240 \\
289 \\
231 \\
410 \\
254 \\
255 \\
149 \\
91.8 \\
182 \\
157 \\
---.-\end{array}$ \\
\hline
\end{tabular}

See footnotes at end of table. 


\section{A-32 STUdies OF SITES FOR NUCLEAR ENERGy FACILITIES}

TABLE 4.-Momentary maximum, minimum daily, and annual mean discharge, in cubic feet per second-Continued

\begin{tabular}{|c|c|c|c|c|c|c|}
\hline \multirow{3}{*}{ Year } & \multirow{3}{*}{$\begin{array}{c}\text { Water- } \\
\text { supply } \\
\text { paper }\end{array}$} & \multicolumn{4}{|c|}{ Water year ending Sept. 30} & \multirow{3}{*}{$\begin{array}{l}\text { Mean for } \\
\text { calendar } \\
\text { year }\end{array}$} \\
\hline & & \multicolumn{2}{|c|}{ Momentary maximum } & \multirow{2}{*}{$\underset{\text { daily }}{\text { Minimum }}$} & \multirow{2}{*}{ Mean } & \\
\hline & & Amount & Date & & & \\
\hline
\end{tabular}

B. Miami River at Sidney, Ohio

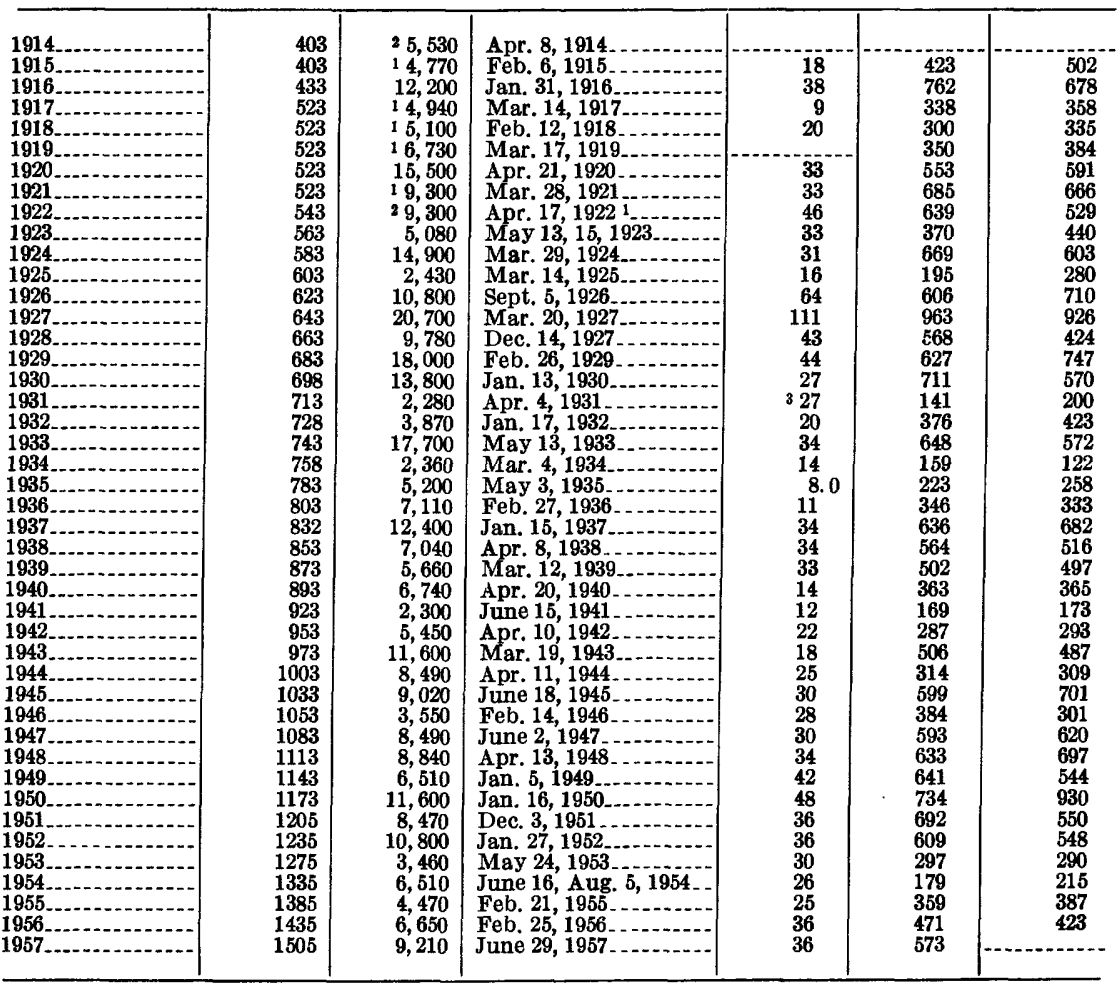

1 Not previously published.

2 Revised.

3 Corrected. 
GEOLOGY AND HYDROLOGY, PIQUA AREA, OHIO A-33

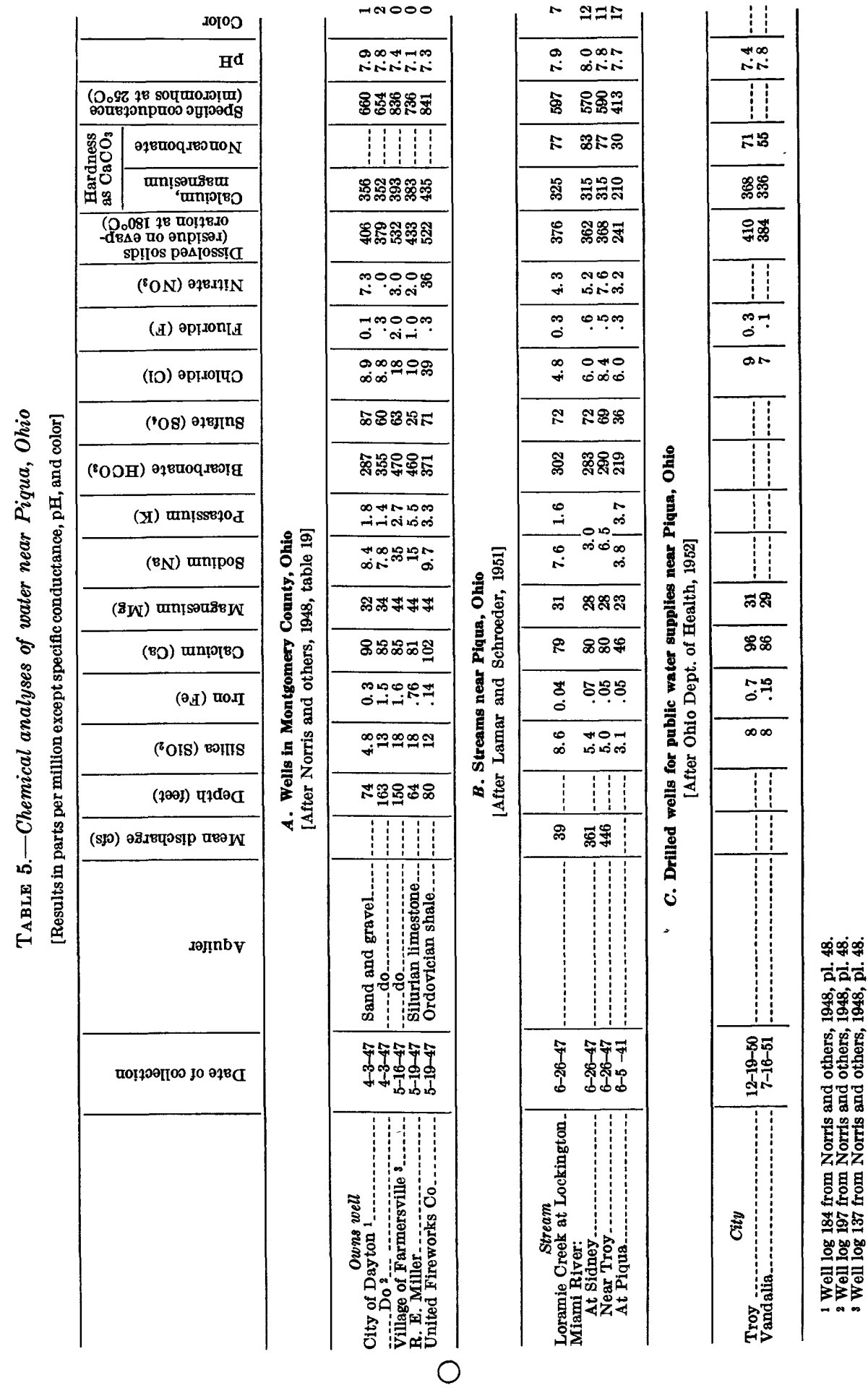




